\title{
TRUST AS AN INSTITUTIONAL FACTOR OF ECONOMIC SUCCESS
}

\author{
Vlastimir Lekovic* \\ Faculty of Economics, University of Kragujevac, Kragujevac, Serbia
}

\begin{abstract}
Trust, as an important traditional informal institution of a society, has in recent decades come into focus of many social sciences and the economic science as well. Namely, trust is one of the key factors that determine the character of both human and social relations. There is a growing realization that, among other key factors of the market system effectiveness and efficiency, economic impacts are also determined by the appropriate level of trust that exists between economic actors. This paper analyzes the role of trust as a facilitating factor that enables a more successful development of economic activities in such an environment where economic actors deal with the problems of information asymmetry, incomplete contracts, an underdeveloped institutional framework, uncertainty etc. It is suggested that trust, both personal and institutional one, is a significant factor in economic success and development. At the same time, trust plays an important role in the successful implementation of a socio-economic transformation, which is especially relevant in transition countries.
\end{abstract}

Keywords: institutional trust, interpersonal trust, social capital, economic success

JEL Classification: E11, J24, 017

\section{INTRODUCTION}

It is generally accepted that a successful economic development of a country requires a developed and flexible institutional environment. In this regard, social sciences give considerable attention to studying the economic, social and psychological nature of trust, as one of the most important informal institutions. Trust is increasingly considered as a factor which represents the principal condition for the successful functioning of the market economy, and therefore an

\footnotetext{
* Correspondence to: V. Lekovic, Faculty of Economics, University of Kragujevac, Dj. Pucara 3, 34000 Kragujevac, Serbia; e-mail: lekovic@kg.ac.rs
}

important element of economic development. Namely, the successful resolution of the complex social and economic problems of a country includes the full mobilization of all relevant structures: the government, the authorities, businesses, citizens, whose interaction and relationships should be based on mutual trust and cooperation. Thus, for instance, for the successful scientific and technological progress and improvement of the competitiveness of an economy, it is necessary to have creative collaboration of all the key factors in the above-mentioned structures, as well as to establish mutual trust. However, in conditions where a society (citizens) does not trust companies and the government, and where the government does not trust companies and at the same time deceives the 
society, a vicious circle is created, which significantly adds to the economic and political chaos in the state. When a society and an economy are dominated by the rules such as "everyone for themselves", "prevent competition" and so forth, when the prevailing atmosphere is that of mutual distrust and other negative phenomena, there are no conditions for the establishment of a compromise and cooperation. It is evident that a lack of trust, as an undesirable state in the economic and social spheres, is one of the key obstacles to achieving successful cooperation between potential business partners.

Under such circumstances, where mutual relations in a business environment are characterized by the absence of trust, reputation does not mean much, and its loss does not prevent unfair business partners to achieve their goals. At the same time, when the functioning of both the government and the companies is characterized by the lack of transparency, the process of obtaining information about potential partners is a difficult one, and such situation is even more complicated by the fact that the institutions that should provide reliable information are poorly developed. These are all pronounced features that characterize the economy and the society in Serbia in the current time period. Since the lack of trust is one of the symptoms of the underdevelopment of the institutional framework of both an economy and a society, this paper points out the positive effects of trust in cases where economic actors are faced with open problems present in every economic system, such as opportunistic behavior, information asymmetry, transaction costs, the principal-agent problem, the building and development of the institutional environment and so forth.

The concept of trust, as the subject matter of the present study, is considered as the key element of social capital which significantly determines the successful realization of economic activities in any economy. By its decisive contribution to the strengthening and developing of social capital, trust, as analyzed in this paper (both personal and institutional), is directly expressed as an important institutional factor in an economic success. In accordance with the aforementioned issue, the aim of this paper is to point out the fact that the favorable business environment is the one established through building personal and institutional trust which, in turn, enhances the successfulness of the business activities, based on the relevant information about the stimulating effect of trust in respect of the successful overcoming of potentially conflicting situations which emerge due to the information asymmetry, incomplete contracts, underdeveloped institutions, and the uncertain future per se. In accordance with the subject matter of this paper and the specified goal of the research, the starting hypothesis whose testing will show the importance of trust in the contemporary economy, is: trust, both personal and institutional one, has positive effects on human capital, investments, the level of transactions costs, the collective organization and governance, and represents the key factor that determines the effectiveness of economic efficiency and growth; hence, trust per se is an important institutional factor in an economic success. In the process of exploring the key aspects of the concept of trust, and based on the confrontation of different theoretical viewpoints on this important economic and social phenomenon for the purposes of this study the analytical descriptive method was applied.

\section{THE CONCEPT OF TRUST AND ITS ROLE IN THE ECONOMY AND SOCIETY}

The concept of trust is a complex and multiform social phenomenon, as evidenced by the fact that this issue is analyzed by philosophers, psychologists, sociologists, economists and political scientists. Over the past few decades, this component of social capital has received much attention, particularly its economic feature, as well as its very important social-psychological nature. There is little doubt about the attitude that trust plays an important role in overcoming the threat of opportunism, and that its presence affects the forms of the organization and level of transaction costs. Namely, in such an environment where trust represents an established category, we have also satisfied active individuals whose productivity will be higher and who will not ask for the government's assistance in resolving any mutual disputes. Consequently, available resources will be used more efficiently and more rationally in implementing the economic goals, which is a major precondition of an economic success. 
The problem of trustis usually analyzed in philosophical and sociological literature from the aspect of different social groups, who have their peculiar notions of fairness, diligence, responsibility, not only in terms of justice and the appropriateness of the processes and phenomena which include the prevailing idea about the legality of the current affairs, but also from the point of the harmonization of the attitudes and aspirations regarding the ongoing efforts and results. Some of the main characteristics of trust, inherent in any social group, can be considered as universal values. At the same time, in one way or another, every social group incorporates its understanding of these values and, based on its own perception of reality, customizes its concept of trust. For example, when the government implements some changes in the society, then these changes, if they are in accordance with the appropriate generally accepted values, will have the trust of the vast majority of the population that will be supportive of these changes. At the same time, the government's action aimed at the protection of the group interests will, in terms of trust, inevitably be ranked differently by different population groups.

As a complex and multifunctional social phenomenon, trust affects the shaping of all aspects of social life, adds to the stability of social relations and promotes cooperation and integration. In brief, trust is important because it is a fundamental assumption of cooperation between people. As such, it represents the most important component of social capital, which Putnam $(1993,167)$ describes as an element positively contributing to the overall economic, social and political advancements of a society. This brings us to the conclusion that trust represents a significant component of the social structure, yet not of the one of an individual. Therefore, one can say that it is a sort of public good, necessary for the establishment and maintenance of the stable social and economic relations. In addition, the role of the institutional norms and institutions is of great importance for the development and maintenance of the complex relationships in a society based on trust, as well as the existence of a mutual correlation between institutions and trust. On the one hand, if a society is characterized by a high degree of confidence, the newly-established institutions will be better accepted, and on the other hand, the introduction of new institutions will have a positive effect on the growth of trust and cooperation. Hence, it can be concluded that the nature of the institutional order is important, and that institutions can generate a culture of trust and cooperation on which the future social and economic development will rest.

The concept of trust is the most fully elaborated in the framework of social capital, which stresses that trust makes one of the key, perhaps the most important, elements of its structure. According to Putnam (1993, 167-169), the importance of trust lies in the fact that it facilitates the cooperative activity and that, as a significant "moral resource", contributes positively to the overall economic, social and political advancement of a society. Putnam draws attention to the fact that trust can be understood as a source of social capital, as well as its result. In essence, the point is that trust and social capital mutually support each other.

Within the concept of the social capital, as an informal norm which allows cooperation between two or more economic actors, Fukuyama $(1999,2002)$ puts an emphasis on trust and norms as its essential components. He points out that trust is the key indicator of social capital; yet, trust itself is not the capital but an important endogenous variable in the functioning of the economic sphere. In this context, Fukuyama believes that trust, as well as social networks and civil society, represent an important side-effect that affects social capital. In addition, social capital is defined as the potential that originates from the dominant relationship of trust in a society or in its parts. Some authors suggest that the elements of social capital are basically the same as the elements of the institutional environment in terms of institutionalists' view; however, there are notable differences between these two theoretical approaches (Нестеренко, 2002, Фукуяма, 2004). The theory of social capital points to the fact that norms, mutual relations, organizations and other elements of social capital are stimulating elements in a business environment. Based on this belief, some theorists (Coleman, 1990; Putnam, 2002) point out that social capital has the capacity of the key resource, both in democratic politics and economic prosperity. In terms of proper quantification, Fukuyama (1999) is of the opinion that trust also has a qualitative dimension, which is difficult to express in the form of economic formulae. Starting from this definition, he believes that 
companies with low levels of trust are not suitable for a rapid economic growth.

Trust is present in all spheres of an economic system as its integral part, but is also an essential integral component of the functioning and development of a socio-economic system. The economic science puts a special stress on the context of trust since no type of investment can be realized without trust. Furthermore, the absence of trust also causes an increase in transaction costs, which, accordingly, creates serious obstacles in the functioning and development of an economy. In accordance with the institutional approach, trust among economic actors is seen as the fulfillment of obligations without the application of sanctions, i.e. the interested parties believe that there is no need for the implementation of particular measures and sanctions regarding the fulfillment of mutual obligations.

According to Fukuyama (1999, 20-21), the economic activity is the key and the most dynamic segment of any society, where, in a principled way, various types of norms, rules, moral obligations and other social values, including trust, which as a universal cultural feature has a prominent role, operate. In this context, it is indicated that the very model of the modern market and market relations is in a special way connected with confidence. If we look at the choice, i.e. the decisionmaking processes of economic actors, we can see that the quality of decisions is determined by trust, which, in a direct way, reflects the level of rationality. This fact brings us to the conclusion that the market itself is a product of the mutual trust of its participants because the market cannot exist in such conditions where everyone would deceive each other. On the contrary, despite the competitive relationship between economic actors, the market implies sincerity and openness of its participants in terms of meeting commitments, and expectations that all other actors will establish identical relationships. Hence, trust between economic agents, which has always played an important role in the socio-economic development, is the most completely manifested precisely in the market economy. As Arrow stresses $(1972,357)$, any commercial operation contains significant elements of trust, especially if its implementation takes some time. In accordance with the aforementioned position, the author believes that a significant part of the economic underdevelopment in the world can be explained by the absence of mutual trust.

Since the subject matter of this study is the most suitable and the most substantial essence of the trust-related issues, it is necessary to conduct an economic analysis in order to gain a more complete understanding of the nature of informal institutions. Additionally, it should be noted that trust is not synonymous with the common conception of a proper treatment. When we talk about trust, it is necessary to bear in mind that this is not a trust in "person as such", but in their abilities, aptitudes, skills, moral characteristics, etc. In this regard, it is necessary to bear in mind that the characteristics such as punctuality, fairness, the character trait of "keeping the word", represent a kind of power, not only moral properties (a business partner can be a good friend, while still always late for work and appointments, which is bad for business).

As an economic category, trust implies such relations between economic agents, where one of the parties, based on the assessment of the moral and commercial properties of the other party, to a certain extent excludes the possibility of opportunistic behavior. As noted, various economic agents, entering a mutual business relationship in terms of an uncertain future, must build their relations based on certain mutual trust. Thus, figuratively speaking, one can say that trust is the "air" necessary for the functioning of normal business activities.

In the modern economic environment, trust has a growing importance not only in the national economy, but also in wider, international relations. Just how important trust is in the international economy is evidenced by the fact that one of the themes of the World Economic Forum held in Davos, 2003, was "Building Trust". And this is an indicator that the growing tendency in modern science is to define trust as a basis of the system of economic cooperation at the global level. The importance of trust as one of the important factors of economic behavior and an economic success is supported by the lessons learned from the financial crisis in 2008. Many anti-crisis programs designed by developed countries have given priority to measures that should result in increased 
trust between governments, banks and borrowers. In Serbia, for example, due to a need to restore confidence in the financial sector, an emphasis is put on increasing the amount of savings guaranteed by the state.

The importance of the trust factor, as the principle condition for the successful functioning of the market economy and economic development, is particularly manifested during the implementation of the very complex socio-economic transformations in transition economies, which, economically speaking, should result in the establishment of a market system. Корнаи (2003) considers that the degree to which this factor is present in a society and an economy makes it easier to understand the causes of the success and failure in transition countries. Many are of the opinion (Стиглиц, 2001) that the lack of trust and the destruction of social capital are one of the most important causes for many failures of the reform process in the post-socialist countries.

Under his concept of the industrial society, Fukuyama $(1999,129)$ emphasizes that the achievement of some of the key tasks of economic life, such as the welfare of the nation and its competitiveness, are conditioned by the level of trust existing in a given society. Fukuyama sees trust as expectations established within a society, those that the members of the society will behave properly and honestly and show willingness for mutual assistance, in accordance with the generally accepted norms. Such trust, which a certain individual counts on, relies on the expectation that the business partner will not draw his/her own benefit from the vulnerability of the mentioned individual, if any.

In other words, trust is a kind of presumption of integrity and honesty in relationships within a certain circle of partners. These are the uncertain, however expected modes of partnership relations. Integrity, which is formed based on the past behavior, leads to the creation of trust in a next activity, which justifies the adoption of the presumption of integrity in business dealings. At the same time, trust is the result of some other activity that affects the choices of individuals, when the individual is required to act in a manner which is known as the action of others (Ostrom, 1998).

The role of trust in socio-economic life is manifold. It contributes to the greater efficiency of the market economy, a successful social partnership and democratic stability, affects personal satisfaction and an optimistic perception of the future, thus stimulating economic growth. There are several aspects through which high levels of trust affect economic performance and economic growth and development:

- An intensive exchange of information, which leads to the facilitated coordination of the interests of economic actors, is established and hence more complete cooperation in the innovation sphere;

- By reducing future uncertainties, future risks associated with the implementation of the major investment projects, as well as the threat of opportunistic behavior, are also reduced;

- The transaction costs related to monitoring and control as well as those of protecting property rights are reduced, which contributes to reducing the burden of the legal system and increases its capacity.

Figure 1 illustrates the possible direction of the effect of trust on some of the key factors, such as investment, human capital management, transaction costs, collective organization and action, which all determine economic success and economic growth.

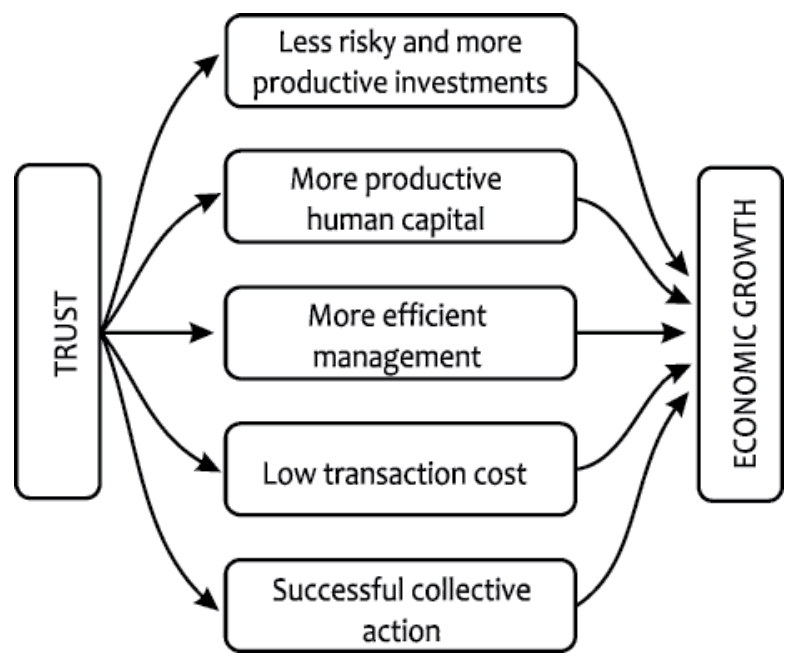

Figure 1 Effect of trust on economic growth 
In the contemporary conditions, the relations characterized by trust are an important prerequisite for the establishment of long-term economic ties and, by transcending the interaction between companies, they begin to exert an increasing influence on economic relations at the macro level. The activities regarding the establishment of trust between states, their leaders, different economic agents from various countries and etc., are also significant.

Although trust is essentially based on the reputation of the company and not on an analysis of specific contractual terms and conditions, this does not necessarily mean that it leads to a restriction of competition, because reputation is, above all, the confidence that is, again, the result of a past behavior; this indicates that the carrier of such reputation will act in the future in accordance with the previously acquired reputation (positive reputation). Trust which is for the most part based on the reputation of a business entity is one of the important instruments in the competitive struggle, so in other words, it can be considered as "reputation competitiveness".

In addition, it is necessary to further consider the substance and content of the socio-economic phenomena such as "institution of trust". The problem of establishing an effective institution of trust is most clearly expressed by the institutional economic science. The works of institutionalists clearly articulate the view that a high level of trust allows companies and individuals to significantly reduce the threat of opportunism, solve the problem of uncertainty and reduce the costs of monitoring and control, whose occurrence is inevitable due to incomplete contracts. In addition, trust encourages a continuous exchange of information, which in turn, by harmonizing different interests of economic entities, prevents significant costs which are associated with protecting property rights.

A previously established confidence level is changed during the conducting of bilateral relations between economic agents, which indicates that the formation of a dynamic process of trust is accompanied by a series of expenditures. These are transaction costs, which are the result of gathering information about the business partners and occasionally incurred expenses due to the maintaining of the business relationships with business partners and etc. This kind of costs can be described as an investment in establishing business relations based on trust. The dynamic nature of trust is manifested in gradually built reputation which suits the trust established between business partners. The reputation is said to be an intangible asset, whose value determines the measure of the reliability with which partners can assess the future behavior of the relevant economic agent. In this respect, reputation can be seen as an implicit contract (Furubotn \& Richter, 2000), which represents a valuable capital for a company. Reputation allows companies to cut costs because it excludes the preparation of detailed contracts which must contain a precise assignation of powers and liabilities. On the other hand, if partners accept reputation and honest behavior as a kind of an ideal, the balance that can have a multiple and much broader social significance is formed. In this sense, reputation should be considered as one of the sources of trust.

\section{BASIC TYPES OF TRUST}

The typology of trust, as one of the most important informal institutions, can be determined according to several criteria. Here, attention is usually directed at distinguishing interpersonal and institutional trust (the trust of people in social institutions and their representatives). Also, a distinction is made between vertical and horizontal trust. Vertical trust implies confidence in social institutions (the government, legislative bodies, churches, trade unions, etc.), while horizontal trust implies trust between people. While speaking about the different types of trust, it should be emphasized that if we consider personal trust as a kind of the foundation of every society, then institutional trust is the basis of the functioning of a complex organized society in which there are various organizations generating and supporting the rules of the game. In this paper, an emphasis is placed precisely on institutional trust - the trust individuals have in social institutions, their representatives, institutional practices and procedures.

It is said that trust which characterizes not only the relations between the entities engaged in continuous 
communication, but also the relations within a system as a whole, represents depersonalized trust, that is, general (social) trust. Trust established in this manner is an important quality of civil society, enabling a better integration of citizens in the common social initiatives. Thanks to this important social feature, i.e. the value of trust, relations of tolerance are formed between people, which makes a society function more successfully. Therefore, some authors (Ostrom, 1998; Uslaner, 2002, Uslaner \& Badescu, 2002) suggest that the development of general trust is the fundamental issue, as well as a significant commitment of each society. In this context, the issues of sources of general trust emerge. The effect of voluntary associations, organizations (both formal and informal ones) and similar structures, and the state, is specially analyzed. It can be noted that the impact of various voluntary associations is ambiguous, which is directly related to their character. In this context, it cannot be expected to increase the level of social trust in the environment where the activities of individual associations are aimed at drawing benefits for their members at the expense of the rest of the society. For example, the formation of supplier cartels, which are formed in order to increase prices, only increases mistrust in consumers concerning these structures.

Many studies (Hall, 1999; Kaas, 1999) indicate that general trust is determined by way of the functioning of the political and judicial institutions. The emphasis is on the relationship between trust in such institutions (institutional trust) and general trust, whose causeeffect relationships have a dual nature. On the one hand, the formation of general trust is supported by the optimistic attitudes towards the existing political institutions, while general trust, on the other hand, is supported by the higher efficiency of state institutions. A more detailed disambiguation of the role of institutions in the development of general trust allows a better perception of the structure of institutions, with particular attention to those who have a significant role in the daily life of citizens. The citizens' assessments regarding the performance of these institutions on the one hand and fairness of their decisions and actions, on the other hand, is characterized by two key aspects of the institutional trust: the efficiency of institutions according and their fairness. In addition, the attitudes towards the activities of institutions at the micro- level are largely transferred to the macro level. Thus, institutional trust significantly affects the overall credibility of a society as a whole, and also represents the building blocks of such a society.

The role of state institutions is very important for the establishment of general trust in a society. The advantages of the institutional concept of trust lies in the fact that personal experience and confidence are not ignored, but are fitted into the overall picture of trust as a social phenomenon. This conclusion is in line with those beliefs (Knack \& Keefer, 1997) which point out that the countries with a lower socio-economic differentiation and a more even distribution of income have higher levels of total (general) trust.

The fact that trust plays an important role in eliminating the threat of opportunism has never been questioned; indeed, trust determines the character of cooperation and influences the organizational form and level of transaction costs. Therefore, trust is increasingly considered as an important factor of an economic success and economic development (Дяско, 2003б). Special attention must be paid to the role of trust in the implementation of a socio-economic transformation, with an emphasis on those processes that are associated with the building of a market economy, which allows for the better understanding of the reasons for the success and failure of transition countries. In this regard, Стиглиц (2001) emphasizes the lack of trust and the destruction of social capital as the limiting factors in implementing reforms.

One of the most complex and most important forms of trust is trust in institutions, primarily the state ones. In addition, institutional trust can be characterized as depersonalized trust in relation to officially established rules, norms and principles. In this context, confidence in the established rules is manifested as trust in organizations that implement these policies. At the same time, trust in companies is transferred to their management. An analysis of institutional trust, in which trust in the state agencies and its representatives is embedded, is essential. Given the nature of institutional trust, this type of trust has its own specific features, compared with interpersonal trust. Interpersonal trust, above all, stands for trust between people who are not acquaintances (in the institutional 
literature, this form of trust is described with the term trust, in general, as opposed to personalized). The relationship between these two types of trust is particularly examined. Institutional trust, which does not refer to specific persons, is understood as the ability (capacity) of a system of rules and organizations.

Bearing in mind that institutional trust is not the result of an attitude to contracts, laws and organizations, but to persons responsible for the implementation of appropriate policies, it can be concluded that this form of trust includes an important personal component. In other words, trust in institutions is a form of trust which is a result of interpersonal relations. In this regard, it is only correct to talk about institutional trust as confidence in institutions, which is on the one hand, created by the people, and, on the other, directly affects the nature of these relationships. In addition, institutions have an important impact not only on the nature of human relationships, but also on the very individuality of a person and the shaping of one's personality by the working process. When a socially organized working task enables an individual to make decisions, take an initiative and a responsibility in the process of work, then this individual fully reveals his/ her potential. Otherwise, there is a risk of a person's degradation to the level of a simple appendage of the machine, which turns him/her into an impersonal entity.

When one person trusts another, he/she expects favorable and non-discriminatory behavior from the other person: therefore, there is no need for such a transaction to be formally controlled (Корнаи, 2003, 5). In this sense, trust becomes a kind of presumption of good faith in relations between the partners. Trust is based on the view that the business partner shall not draw his/her own benefit from the possible weakness of his/her counterpart, but will act honestly, and show willingness for mutual assistance, in accordance with the generally accepted rules and norms. Hence, the fact that the business entities are not only ready to formally accept the rules, but also to respect them, makes an important element of the trust mechanism. In addition, this suggests that trust in institutions is determined by the level of their compliance with the expectations of economic entities, i.e. the assessment of these entities regarding the manner in which these institutions were formed in terms of their efficiency and fairness. This leads to the conclusion that institutional trust is established more completely in such an environment where the institutions function efficiently and fairly.

The issue of trust in a state and its institutions has a particularly specific weight, given their role as the creators and guarantors of the institutional environment. The level of trust in the state is determined by two essential components. One of them relates to how efficiently government institutions enable the carrying out of economic activities (regardless of whether it comes to creating the necessary conditions for effective competition or the participation of the state in the economic process). The second component relates to the fairness of the institutions (the formal content of the established rules, mechanisms of their development and adoption, the structure of the organization). Namely, it is important that the existing state institutions be effective in meeting the main objectives of the economy, and that, on the one hand, they be addressing the issues of a fair arrangement in the best possible way and, on the other, be contributing to the achievement of the maximum economic efficiency. It should be noted that both these conditions are interrelated and mutually determined by considering that:

- In the design of the state economic policies it must be understood that without economic efficiency, it is not possible to achieve desired material results, which would enable the improvement of the quality of living of the citizens;

- By ignoring the principles of fairness, it would be difficult to achieve a desired economic efficiency.

\section{INSTITUTIONAL TRUST AND ECONOMIC EFFICIENCY}

The institutional structure of a national economy, which is composed of the totality of its formal and informal institutions and mechanisms for their implementation and compliance, is an essential factor for an efficient resource allocation and economic development. Its role is essential in solving relevant problems, not only in terms of the coordination of activities in an 
environment of the limited rationality of the actors, but also in the distribution of conflicts, given that economic agents pursue their own economic interests. The role of institutions, both formal and informal, is manifested in the fact that, due to their effective operation, these institutions substantially contribute to reducing transaction costs, thereby positively affecting the successful performance of a country's economic activities.

As far as the set of informal institutions is concerned, it is important to emphasize the role of historical and cultural heritage, ideology, and so forth. In this context, moral norms have particular significance since they support the system of values in a society and at the same time affect the establishment of the rule of law and its implementation. By developing the value system of a society, favorable conditions for exercising trust between actors in the economy are achieved, which, in the conditions of asymmetric information, facilitates the process of the economic exchange and in this way supports the establishment of an efficient set of formal institutions, i.e. the system of laws and rules that structures social interaction and the economic exchange, which is an essential prerequisite for an effective and efficient development of economic activities.

Simultaneously, such relationships contribute to the growth of trust in government institutions, which is significant given the complementarity between the existing level of trust and the efficiency of the government. When the trust in government institutions is low, the pressure on the state officials to better and more responsibly perform their duties is weak. Poor governance reduces trust, which causes inferior economic performance. In contrast, in the conditions where the high levels of social trust are present, one can exert stronger public pressure on the government officials, resulting in more efficient public management, which is an essential prerequisite of the business environment that is favorable for the development of economic activities. This is particularly important in the context of the fight against corruption, given that constant public scrutiny over public officials is the most effective means of making them behave in accordance with the defined rules. Thus, trust in state institutions increases, as well as the reliability and efficiency of the established formal institutional framework.

General trust affects economic performance through macro-political channels, primarily due to the quality of institutions. In this regard, countries with more developed formal institutions that effectively protect property rights, contract compliance and enforcement, have more favorable conditions for the establishment and enhancement of mutual trust. This suggests that, under the mentioned conditions, a higher level of trust has positive effects on economic performance, as well as the rate of economic growth.

An analysis of economic exchange implies transactional rationality, where the rationality of choice is based on the difference between a transactional profit and transaction costs. In order to achieve the rational functioning of the system, institutions must exert control over the costs during the establishment and enforcement of contractual relations. Therefore, the activity of establishing an institutional framework that will be trusted implies a certain amount of costs which are inevitable and desirable (Furubotn \& Richter, 2008). In fact, such an institutional framework contributes to the establishment of trust, which has a positive impact on economic performance and is reflected through positive outcomes in case collective problems arise. Thus, better co-operation is established, which results in lower transaction costs and a greater market efficiency. At the same time, social trust reduces the costs related to the prevention of opportunistic behavior; thus a society, instead of investing in monitoring and supervising, directs its resources towards productive investments.

Trust between economic actors as well as institutional trust influence the level of economic performance and therefore affect movements in the GDP per capita. Namely, trust as a result of the repeated interaction between economic partners causes the expansion of economic activities. At the same time, trust as an informal institution influences the development of formal institutions, which in turn promote trust and thereby exert positive effect on increasing the level of economic success. Individuals who successfully work together strengthen the level of trust and develop an informal institution of the agreement, which is 
essential in resolving any disputes that might arise during the utilization of shared resources.

Pointing out to the importance of the issue of trustallows for the better understanding of the methods used to maintain the vitality of an economy in an environment of asymmetric information, incomplete contracts and an uncertain future per se. Information asymmetry, as a situation in which some parties to business transactions may have an information advantage over others, results in moral risk or moral hazard, in terms of possibilities to exploit such advantages. The spreading of the consequences of different levels of information which certain economic agents possess leads to the so-called adverse selection in terms of the misrepresentation of private information, in view of concluding a contract that will be more beneficial for one of the parties to the contract and thus result in the inefficient functioning of the market. In order to ensure the transaction, the less-informed party is forcedto spend his/her funds on collecting additional information and formulating more complex and more complete contracts. However, trust reduces the need for such expenditures.

Under the conditions of information asymmetry and incomplete contracts, trust is a kind of catalyst for the economic activity. Its role is important, both in terms of the pre-contractual and post-contractual information asymmetry. An asymmetry in the available information leads to an adverse selection as a form of pre-contractual opportunism, based on which some seller may achieve a short-term benefit. Thus, incomplete information leads to the inefficient functioning of the market mechanism. Establishing a relationship of trust between a seller and a buyer is one way to prevent such developments. Trust, in the aforementioned case, means that the seller is expected not to misuse the fact that the buyer is less informed and sell goods at a higher price. Such trust can be established from various sources, ranging from the earlier transactions that resulted in a certain reputation to customer's assessment of the seller's intentions to achieve the long-term growth of his/her business. It is almost impossible for the seller to count on the growth of his/her business if he/she deceives the customer. Another option would be the drawing up of a more detailed purchase contract, which would specify the parameters of the quality of goods and the obligations of the seller in case the goods sold do not match the specified parameters. This option involves additional transaction costs, incurred both by preparing such a contract and forcing the retailer to meet its obligations, which further burdens the business transaction.

Also, in the familiar principal-agent relation, in terms of their different post-contractual information on the subject of the contract, there is a potential moral hazard in the form of post-contractual opportunism. It appears at the end of the contractual relationship, when the partner who is better informed, maximizes his/her benefits at the expense of the other partner. Such a possibility is moderated by the growth of trust between the principal and the agent. Trust, in this particular case, involves the principal's expectation that the agent will not to abuse the fact that he/she is better informed, on the one hand, and, on the other, the agent's expectation that his conscientious work will adequately be rewarded by the principal. Sources of such trust may be different: the agent's reputation, personal relationships and the like. One possible approach to solving the principal-agent problem can be found in the so-called incentive contracts, which actually represent a cry for rational trust. The fact that, from the manager's perspective, there cannot exist an ideal contract is supported by the fact that complete rational trust between owners and managers does not exist. However, it is reasonable to expect the optimal level of trust between them.

In an attempt to speed up the process of the socioeconomic development, which includes developed and consistent institutions, one often opts for a transplant or import of institutions. Here, we are talking about the transfer of institutions which are formed in a certain more developed institutional environment, to another, less developed one (Полтерович, 2001, 24-50). As practice shows, the Serbian experience included, this type of lending often proves unsuccessful. The answer to the question why this happens can be found in the institutional concept of trust. In fact, the level of trust in transplanted economic institutions depends on the assessment of their effectiveness in the recipient country on the one hand, and on the other hand, the assessment of the implications of state institutions on social justice, which depends on the manner in which 
certain institutions are implemented. For example, trust in the privatization of housing units differs from trust in the privatization of companies and the infrastructure. Inadequate communication during the mass privatization resulted in the absence of an efficient system of property rights, increasing trust in the institution of the private property instead; a completely opposite situation occurred, which undermined trust in the competent institutions, especially the judiciary ones.

A negative rating of the effects of the transplantation of new institutions into the system, in terms of social justice, represent the catalyst for the mass opportunistic activities, in relation to both such and other institutions. This opportunism can be manifested as demand for such institutions which do not correspond to the official reform logic, which, in accordance with such logic, reduces the capacity of the introduced institutions. This indicates that the lesser the trust in the new institutions, the greater the costs of implementation and support to their survival. Thus, the transaction costs of their use become high. The manner in which low trust is manifested in high transaction costs can most clearly be seen in the difficulty in the realization of the rights of ownership.

The practice has confirmed that the absence of effective mechanisms for the protection of property rights and contractual liabilities increases risk on the capital market, leading to the paralysis of the investment and innovation activities at the micro level. In this sense, North $(2003,77)$ considers that the inability of a society to ensure that contracts are carried out efficiently and at a low cost, in qualitative terms represents the most important cause of the stagnation and underdevelopment of the Third World Countries. The key indicators of the protection of property rights and contractual liabilities lie in an efficient judicial system, the rule of law, a degree to which corruption is present, the risk of confiscation and the risk of breaching a contract. It is undisputed that the state plays the key role in the implementation of property rights through regulation, supervision and judicial-legal procedures. However, along with a request for the improvement of the legal system, the need to increase the level of trust between business partners has increasingly been emphasized in recent years (Мильнер, 1997; Аяско, 2003a).

Mutual trust between economic agents and the precise specification of property rights result in lower demand for public and private legal mechanisms for the protection of property rights and contractual liabilities. Specifically, the greater the mutual trust between business partners, the lesser the litigation processes. According to Корнаи $(2003,8)$, if there is less pressure on the judiciary to speed up the legal procedures, trust in the judiciary and bureaucratic mechanism will increase. The end result is indisputable: the higher the level of trust between trading partners, the lower the transaction costs. At the same time, the savings in the current transaction costs can be achieved on account of the transaction costs incurred during the building of trust. It is therefore necessary to take such costs into account when analyzing the economic role of trust (Ляско, 2003б).

However, each level of trust between business partners corresponds with an adequate level of mutual control. In fact, maintaining a relationship of trust does not involve the complete renunciation of monitoring and control. Rather, we can talk about trust relying on certain control. Introducing the additional monitoring and sanctioning mechanisms which exist in a supposedly developed and established relationship of trust between the business partners, indicates that trust between such partners actually never existed. When a partner is, so to speak, out of the framework of control, he sends a signal to the partners that the relations of mutual trust have been exhausted to a certain extent and that they need to be rebuilt in order to maintain a reliable relationship (Дяско, 2003a). At the same time, relations of trust are very diverse and, in some cases, may have a different role in a society. Thus, the relationship of trust between the members of criminal groups, and between those who give and those who accept bribe, harms other members of such a society. From the example of the famous prisoner's dilemma, we conclude that the higher the degree of trust between the offenders, the more difficult for the judicial system to successfully implement its mission.

The conceptual views on the role of trust in economic development have received confirmation in the 
analytical models and statistical observations. In a series of empirical studies, a correlation between trust and economic growth has been identified (Knack \& Keefer, 1997). Based on the model of equilibrium growth, it was confirmed that a society with low levels of trust might easily fall into poverty trap (Zak \& Knack, 2001).

The crisis of trust which is present in the domestic economy and which occurred in the 1980s, was even deepened due to the implementation of the transition activities in the past two decades. The orientation on the implementation of the socio-economic transformation by a narrow range of coordination mechanisms was not suitable for overcoming the crisis of trust and thus led to contradictory results. These results may serve as an illustration of the economic development which results in a lack of trust. The destruction of the old social and organizational capital, without a corresponding emphasis on creating the new one, had a significant impact on the economic and social failures in the present period of transition, as pointed out by Стиглиц (2001, 114). It can be argued that many of the essential characteristics of the domestic economy are the consequences of the adapting of the economic actors to the conditions characterized by a lack of confidence, both in relations between firms and in relations with the state. For example, in a certain period of transition, barter, as the simplest form of exchange, was present in Serbia. This was conditioned, among other economic and political reasons, by the lack of trust between business partners.

\section{CONCLUSION}

Numerous analyses, as well as the economic reality, have shown that the existence of trust between economic actors is crucial for the successful functioning and stability of an economy. Namely, economy does not only require a proper institutional arrangement, but also appropriate social relationships that will contribute to the building of trust. In transition societies, it is precisely the lack of trust in economic, cultural and political spheres that represents an important obstacle to building a civil society without which there is no responsible government and therefore no essential preconditions for political and economic stability.
At the same time, numerous problems, both economic, and social ones, faced by countries in transition, are most frequently seen as a consequence of underdeveloped institutions and a low level of trust. In addition, although a full responsibility for a number of open issues of the transition process cannot be assigned to the institutional component, every analysis of the effects of the current socio-economic transformation in transition economies, which would neglect just one of the mentioned factors, would result in incomplete and one-sided conclusions. Hence, the conclusion is that the lack of trust is one of the causes of the failed reforms in the former socialist countries. Simultaneously, in all countries where reform programs were implemented consistently and in the proper manner, the level of general trust was significantly raised, thus, all actors manifested their full readiness to support the reform processes and to actively participate in them. The ultimate result of the properly designed and consistently implemented activities is an increased economic success of economic actors and dynamic economic growth, which indicates that there is a positive correlation between socioeconomic stability and economic growth, on the one hand, and all forms of trust in a society, on the other. Hence, it can be concluded that the level of trust in a society is actually an indicator of the society's "health" and vitality.

If we look at Serbia, which is characterized by a deep and prolonged economic crisis (high levels of the foreign debt and trade deficit, an extremely high unemployment rate and the emigration of young and educated people, the impoverishment of the population, the de-industrialization of the country), the crime and corruption rates increase, the absence of the will to strengthen the institutional capacities of both the society and the economy, are clear reasons for the lack of trust which is present in all segments of the Serbian society. When the government is not ready to design comprehensive and consistent reform programs, and more efficiently implement the promised reforms, when the government does not create an institutional environment that will stimulate the economic activity and economic growth, it is logical that new forms of distrust in a society will emerge. In such circumstances, there is little opportunity for the strengthening of 
social trust, which is the key condition for achieving more complete social cooperation. The countries where transition processes have successfully been carried out represent quite the opposite example. The experience of these countries shows that trust can be built relatively quickly as the key indicator of social capital, which is an essential prerequisite for achieving an economic success and economic growth and development.

The World Bank report for 2011 emphasizes that, even in developing countries, it is possible to reach a satisfactory level of trust strengthening in one generation, as well as a more successful transformation and building of economic institutions, which is an important guarantee for the safety and fairness of the citizens. However, this implies that the governing structures of the country must be dedicated to a substantive institutional reform and focus primarily on strengthening the institutional capacity of a country, because the legitimacy of institutions is a guarantee of the stability of the economy and the society, as a basis for an improved economic success and a more rapid growth and development. For a successful transformation of the basic institutions, strengthening the social and personal confidence in the key social activities which aim to improve the institutional environment is essential. The conclusions that we have reached in this paper, those confirming the existence of a positive correlation between trust and institutional development, on the one hand, and economic performance, on the other, indicate the necessity of a clearly formulated strategy for improving the institutional infrastructure of the economy and the society, as well as the value system of the society in which trust has an important role. Due to their contemporariness, the issues of trust and institutional infrastructure as the determinants of economic and social development will undoubtedly be the subject matter of future research, in order to make an appropriate contribution to the establishment of an economic, institutional and social environment which would be suitable for improving economic performance of the Serbian economy based on the adequate scientific method and by applying a proper methodology.

\section{ACKNOWLEDGEMENTS}

The research in this paper was conducted within Project No. 179015, funded by the Ministry of Science of the Republic of Serbia.

\section{REFERENCES}

Aroww, K. J. (1972). Gifts and Exchanges. Philosophy and Public Affairs, 1(4), 343-362.

Coleman, J. S. (1990). Foundations of Social Theory. Cambridge, Massachusetts: The Belknap Press of Harvard University Press.

Fukuyama, F. (1999, October 1). Social Capital and Civil Society. Paper presented at the IMF Conference on Second Generation Reforms, The Institute of Public Policy, George Mason University.

Fukuyama, F. (2002). Social Capital and Development: The Coming Agenda. SAIS Review, XXII(1), 23-37.

Фукуяма, Ф. (2004). Доверие. Социиальные добродетели и путь к процветанию. Москва, Россиа: ООО Издательство АСТ : ЗАО НПП Ермак.

Furubotn, E. G., \& Richter, R. (2000). Institutions \& Economic Theory: The Contribution of The New Institutional Economics. Michigan, USA: The University of Michigan Press.

Furubotn, E. G., \& Richter, R. (2008). Institutions \& Economic Theory. Michigan, USA: The University of Michigan Press.

Hall, P. (1999). Social Capital in Britain. British Journal of Political Science, 29(3), 417-464.

Kaase, M. (1999). Interpersonal Trust, Political Trust and Noninstitutionalised Political Participation in Western Europe. West European Politics, 22(3), 1-22.

Knack, S., \& Keefer, P. (1997). Does social capital have an economic payoff? A cross-country investigation. Quarterly Journal of Economics, 112(4), 1251-1288.

Корнаи, Я. (2003). Честность и доверие в переходной экономике. Вопросы экономики, 9, 4-17.

Пяско, А. (2003а). Межфирменное доверие и шумпетерианские инновации. Вопросы экономики, 11, 27-40.

Пяско, А. (2003б). Доверие и трансакционные издержки. Вопросы экономики, 1, 42-58.

Мильнер, Б. 3. (1997). Фактор доверия при проведении экономических реформ. Вопросы экономики, 11. 27-38. 
Нестеренко, А. Н. (2002). Новые требования и методы взаимодействия организаций с институциональной средой. Управление социально-экономическим развитием России. Москва, Россиа: Экономика.

North, D. C. (2003). Institucije, institucionalna promjena $i$ ekonomska uspješnost. Zagreb, Croatia: Masmedia.

Ostrom, E. (1998). A Behavioral Approach to the Rational Choice Theory of Collective Action. American Political Science Review, 92(1), 1-22.

Полтерович, В. М. (2001). Трансплантация экономических институтов. Экономическая наука современной России, 3 , 24-50.

Putnam, R. D. (1993). Making Democracy Work. Princeton: Princeton University Press.
Putnam, R. D. (Ed.). (2002). Democracy in Flux: Social Capital in Contemporary Societies. New York, NY: Oxford University Press.

Стиглиц, Дж. (2001). Quis costodiet ipsos custodies? Неудачи корпоративного управления при переходе к рынку. Экономическая наука современной России, 4, 108-146.

Uslaner, E. (2002). The Moral Foundation of Trust. New York, NY: Cambridge University Press.

Uslaner, E., \& Badescu, G. (2002, November 22-23). Honesty, Trust and Legal Norms in the Transition to Democracy. Paper presented at the Conference, Workshop on Formal and Informal Cooperation, Budapest.

Zak, P. J., \& Knack, S. (2001). Trust and grouth. The Economic Journal, 111(470), 295-321.

Vlastimir Lekovic is an Associate Professor at the Faculty of Economics, University of Kragujevac, Kragujevac, Serbia. He teaches the following courses: Comparative Economic Systems and Economics of the Public Sector. He received his Ph.D. in Economics from the Faculty of Economics, University of Kragujevac, in the field of economic systems. The key areas of his research interests include economic systems, economic policies and institutional economics. 


\title{
POVERENJE KAO INSTITUCIONALNI FAKTOR EKONOMSKE USPEŠNOSTI
}

\author{
Vlastimir Leković* \\ Ekonomski fakultet Univerziteta u Kragujevcu
}

\begin{abstract}
Poverenje, kao bitna tradicionalna neformalna institucija društva, u poslednjih par decenija predmet je značajnije pažnje društvenih nauka, pa i ekonomske. Radi se o jednom od ključnih faktora koji opredeljuje karakter kako međuljudskih, tako i ukupnih društvenih odnosa. Sve više preovladava shvatanje da $\mathrm{su}$, uz ostale bitne faktore efektivnosti i efikasnosti tržišnog sistema, ekonomski učinci determinisani i odgovarajućim nivoom poverenja, koje vlada između ekonomskih aktera. U radu se analizira uloga poverenja kao podsticajnog faktora uspešnijeg odvijanja ekonomskih aktivnosti u uslovima suočavanja ekonomskih subjekata sa problemima asimetričnih informacija, nepotpunih ugovora, nerazvijenog institucionalnog okvira, neizvesnosti i sl. Ukazuje se na to da je poverenje, kako personalno, tako i institucionalno, bitan faktor ekonomske uspešnosti, kao i ekonomskog razvoja. Istovremeno, poverenje ima značajnu ulogu u pogledu uspešnijeg sprovođenja društveno-ekonomskih transformacija, što je posebno aktuelno u zemljama u tranziciji.
\end{abstract}

Ključne reči: institucionalno poverenje, međuljudsko poverenje, socijalni kapital, ekonomska uspešnost

JEL Classification: E11, J24, 017

\section{UVOD}

Opšteprihvaćeno je stanovište da je za uspešan ekonomski razvoj zemlje potrebno razvijeno i fleksibilno institucionalno okruženje. $U$ tom smislu, u okviru društvenih nauka, sa značajnom pažnjom izučava se kako ekonomska, tako i socijalnopsihološka priroda poverenja, kao jedna od značajnijih neformalnih institucija. Poverenje se sve ćešce razmatra u svojstvu faktora koji predstavlja principijelni

\footnotetext{
* Korespondencija: V. Leković, Ekonomski fakultet Univerziteta u Kragujevcu, Đ. Pucara 3, 34000 Kragujevac, Srbija; e-mail: lekovic@kg.ac.rs
}

uslov uspešnog funkcionisanja tržišne ekonomije, a samim tim i značajnog činioca ekonomskog razvoja. Naime, uspešno rešavanje kompleksnih društvenih i ekonomskih problema jedne zemlje podrazumeva punu mobilizaciju svih relevantnih struktura vlasti, biznisa, građana, u čijim su relacijama poželjni odnosi uzajamne saradnje i poverenja. Tako, recimo, za uspešan naučno-tehnološki napredak i unapređivanje nivoa konkurentnosti ekonomije, neophodna je stvaralačka saradnja svih ključnih faktora u navedenom strukturnom nizu, kao i njihovo uzajamno poverenje. Međutim, u uslovima kada društvo (građani) ne veruje biznisu i vlasti, kada vlast ne veruje biznisu i obmanjuje društvo, uspostavlja se začarani krug, čime 
se podstiče stanje ekonomskog i političkog haosa. Kada su u društvu i ekonomiji dominantna pravila „svako za sebe “, ,onemogući konkurenciju“ i sl. kada preovladava stanje uzajamnog nepoverenja i drugih negativnih pojava, ne postoje uslovi za uspostavljanje kompromisa i saradnje. Evidentno je da odsustvo poverenja, kao nepoželjno stanje u ekonomskoj i društvenoj sferi, predstavlja jednu od ključnih prepreka za ostvarivanje uspešnije saradnje između potencijalnih partnera.

U uslovima u kojima uzajamne odnose u poslovnim relacijama karakteriše odsustvo poverenja, reputacija malo znači, a njen gubitak ne sprečava nepoštene partnere da ostvare svoje namere. Istovremeno, kada u funkcionisanju vlasti i biznisa ne postoji puna javnost, otežano je prikupljanje informacija o potencijalnim partnerima, a institucije koje bi mogle da obezbede pouzdanu informaciju još uvek su slabo razvijene. Sve su to određena svojstva koja karakterišu ekonomiju i društvo u Srbiji u savremenom periodu. S obzirom na to da je odsustvo poverenja jedan od simptoma nerazvijenosti institucionalnih okvira privrede i društva, $u$ radu se ukazuje na pozitivne efekte poverenja u slučajevima suočavanja ekonomskih aktera sa otvorenim problemima svakog ekonomskog sistema, kao što su: oportunističko ponašanje, asimetrične informacije, transakcioni troškovi, problem principalagent, izgradnja i razvijanje institucionalnog ambijenta i sl.

Koncept poverenja, kao predmet istraživanja $u$ ovom radu, razmatra se u svojstvu ključnog elementa socijalnog kapitala, koji bitno determiniše uspešnost odvijanja ekonomskih aktivnosti u svakoj ekonomiji. Odlučujućim doprinosom jačanju i razvoju socijalnog kapitala, poverenje, koje se $u$ radu razmatra kao personalno i institucionalno, neposredno se ispoljava kao bitan institucionalni faktor ekonomske uspešnosti. U skladu sa predmetom, cilj istraživanja $\mathrm{u}$ ovom radu jeste da, na bazi relevantnih saznanja o podsticajnom delovanju poverenja u pogledu uspešnog prevazilaženja potencijalnih konfliktnih situacija do kojih, izvesno je, dolazi u uslovima asimetričnosti raspoloživih informacija, nepotpunih ugovora, nerazvijenih institucija, i per se neizvesne budućnosti, ukažemo na to da se razvijanjem personalnog $\mathrm{i}$ institucionalnog poverenja uspostavlja poslovni ambijent koji podsticajno deluje na uspešnost odvijanja ekonomskih aktivnosti. Shodno opredeljenom predmetu i postavljenom cilju istraživanja, polazna hipoteza, čijim testiranjem će se ukazati na važnost poverenja u savremenoj ekonomniji, jeste: poverenje, kako personalno, tako i institucionalno, pozitivno utiče na ljudski kapital, investicije, nivo transakcionih troškova, kolektivno organizovanje i upravljačke funkcije, kao ključne faktore koji determinišu ekonomsku efektivnost i efikasnost i privredni rast, pa je i ono samo bitan institucionalni faktor ekonomske uspešnosti. U procesu istraživanja ključnih aspekata koncepta poverenja, a na osnovu sučeljavanja različitih teorijskih stanovišta o ovom značajnom ekonomskom i društvenom fenomenu, dominantno je primenjen metod analitičke deskripcije.

\section{POJAM POVERENJA I NJEGOVA ULOGA U PRIVREDI I DRUŠTVU}

Kategorija poverenja je kompleksan i višeznačan društveni fenomen, na šta ukazuje i činjenica da se ovom problematikom bave filozofi, psiholozi, sociolozi, ekonomisti, politikolozi. Tokom poslednjih par decenija, na ovu komponentu socijalnog kapitala usmerava se sve veća pažnja, posebno na ekonomsku, ali i na, veoma bitnu, socijalno-psihološku prirodu poverenja. Malo ko dovodi u sumnju stav da poverenje igra značajnu ulogu u prevazilaženju opasnosti od oportunizma, i da, svojim prisustvom, utiče na forme organizacije i na nivo transakcionih troškova. Naime, uspostavljeno poverenje ima za rezultat zadovoljne i aktivne pojedince, čija će produktivnost biti veća i kojima neće biti neophodna pomoć države prilikom rešavanja eventualnih međusobnih sporova. Shodno tome, prilikom ostvarivanja ekonomskih ciljeva raspoloživi resursi biće upotrebljeni na racionalniji način, što je pretpostavka veće ekonomske uspešnosti.

U filozofsko-sociološkoj literaturi, problem poverenja najčešće se razmatra sa pozicija postojanja različitih socijalnih grupa, sa njima svojstvenim shvatanjima pravičnosti, savesnosti, odgovornosti, ne samo $u$ pogledu pravde, adekvatnosti procesa i fenomena, sa preovlađujućom predstavom o legalnosti onoga što se dešava, već i u smislu usklađenosti težnji i stavova u pogledu tekućih napora i rezultata. Neke od osnovnih 
karakteristika poverenja, koje su svojstvene svakoj socijalnoj grupi, mogu se smatrati univerzalnim vrednostima. Istovremeno, svaka socijalna grupa, na neki način, unosi svoje shvatanje tih vrednosti i, na osnovu sopstvene percepcije stvarnosti, transformiše kategoriju poverenja. Na primer, kada država sprovodi određene promene $u$ društvu, tada će one, ukoliko su u skladu sa odgovarajućim opšteprihvaćenim vrednostima, uživati poverenje ogromne većine stanovništva koje će te promene podržati. Istovremeno, aktivnosti države koje su usmerene ka zaštiti grupnih interesa, neizbežno će biti, prema uslovima poverenja, različito rangirane od strane različitih populacionih grupa.

Kao složen i multifunkcionalan društveni fenomen, poverenje utiče na oblikovanje svih aspekata društvenog života, doprinosi stabilnosti društvenih odnosa, promoviše saradnju i omogućava integraciju. Jednom rečju, poverenje je značajno zato što se radi o temeljnoj pretpostavci saradnje između ljudi. Kao takvo, ono predstavlja najvažniju komponentu socijalnog kapitala, za koji Putnam $(1993,167)$ kaže da pozitivno doprinosi sveukupnom ekonomskom, socijalnom i političkom napretku društva. To nas upućuje na zaključak da je poverenje svojstvo socijalne strukture, a ne pojedinca. Zbog toga se može reći da je ono svojevrsno javno dobro, neophodno za uspostavljanje i održavanje stabilnih društvenih i ekonomskih odnosa. Pri tome, uloga institucija i institucionalnih normi od izuzetnog je značaja za nastanak i održavanje širokih odnosa poverenja u društvu, uz postojanje uzajamne korelacije između institucija i poverenja. S jedne strane, ukoliko je u društvu prisutan visok stepen poverenja, novouspostavljene institucije će biti bolje prihvaćene, a s druge strane, uvođenje novih institucija će pozitivno uticati na rast poverenja i saradnje. Otuda proizilazi zaključak da je karakter institucionalnog poretka važan, kao i da institucije mogu da generišu kulturu poverenja i saradnje na kojoj se temelji dalji društveni i ekonomski razvoj.

Koncept poverenja najpotpunije je razvijen $u$ okviru teorije socijalnog kapitala, $\mathrm{u}$ kojoj se naglašava da poverenje predstavlja jedan od ključnih, možda najvažnijih, elemenata $u$ njegovoj strukturi. Prema Putnamu (1993, 167-169), značaj poverenja sastoji se $\mathrm{u}$ tome što ono omogućava i olakšava kooperativne aktivnosti i što, kao značajan "moralni resurs", pozitivno doprinosi sveukupnom ekonomskom, socijalnom i političkom napretku društva. Istovremeno, ukazuje se na to da poverenje može da se posmatra kao izvor socijalnog kapitala, ali i kao njegov rezultat. U suštini, radi se o tome da se poverenje i socijalni kapital uzajamno učvršćuju.

U okviru koncepta socijalnog kapitala, kao neformalne norme koja omogućava kooperaciju između dva ili više ekonomskih aktera, Fukuyama (1999, 2002) akcenat stavlja na poverenje i norme kao njegove bitne komponente. Pri tome ukazuje na to da je poverenje ključni indikator socijalnog kapitala, ali da ono samo nije kapital iako predstavlja značajnu endogenu varijablu $\mathrm{u}$ funkcionisanju ekonomske sfere. U tom kontekstu, Fukujama smatra da poverenje, kao i socijalne mreže i građansko društvo, predstavlja značajnu propratnu pojavu koja utiče na socijalni kapital. Pri tome, socijalni kapital definiše kao potencijal koji proističe iz dominantnog odnosa poverenja u društvu ili u njegovim delovima. Pojedini autori ukazuju na to da su elementi socijalnog kapitala $u$ osnovi isti kao i elementi institucionalne sredine, $u$ obliku $u$ kojem je ona shvaćena od strane institucionalista, pri čemu su primetne razlike između ova dva teorijska pristupa (Нестеренко, 2002; Фукуяма, 2004). U teoriji socijalnog kapitala ukazuje se na to da norme, uzajamne veze, organizacije i drugi elementi socijalnog kapitala predstavljaju podsticajne elemente okruženja ekonomskog subjekta. Na bazi takvog stava, neki teoretičari (Coleman, 1990; Putnam, 2002) ističu da socijalni kapital ima svojstvo ključnog resursa, kako za demokratsku politiku, tako i za ekonomski prosperitet. U pogledu odgovarajuće kvantifikacije, Fukuyama (1999) je na stanovištu da poverenje ima određenu kvalitativnu dimenziju, koju je teško iskazati u obliku ekonomske formule. Polazeći od ovakvog određenja, on smatra da društva sa niskim nivoom poverenja nisu pogodna za brz ekonomski rast.

Kao neotuđivi deo, ali i bitna integraciona komponenta funkcionisanja i razvoja društveno-ekonomskog sistema, poverenje je prisutno $\mathrm{u}$ svim njegovim sferama. U ekonomiji, ovoj kategoriji pripada posebno mesto budući da bez poverenja nisu moguće investicije, transakcioni troškovi rastu, što, u skladu s tim, stvara ozbiljne prepreke tokom funkcionisanja i razvoja 
ekonomije. U skladu sa institucionalnim pristupom, poverenje između ekonomskih aktera shvata se kao ispunjavanje obaveza bez primene sankcija, odnosno, prisutno je uverenje da za ispunjavanje uzajamnih obaveza ne postoji potreba za primenom odgovarajućih mera i sankcija.

Prema Fukuyama-i (1999, 20-21), ekonomska aktivnost predstavlja ključni i najdinamičniji segment društvenog života, a u njoj, na principijelan način, deluju različite vrste normi, pravila, moralnih obaveza i drugih društvenih vrednosti, među kojima poverenje, kao univerzalna kulturološka karakteristika, ima zapaženu ulogu. U tom kontekstu, ukazuje se na to da je sam model savremenog tržišta i tržišnih odnosa, na poseban način, povezan sa poverenjem. Ako posmatramo izbor, tj. donošenje odluka ekonomskih aktera, njihov kvalitet determinisan je poverenjem, što se, na neposredan način, odražava i na nivo racionalnosti. Ta okolnost implicira zaključak da je i samo tržište produkt uzajamnog poverenja njegovih učesnika, jer tržište ne može da postoji u uslovima u kojim bi svako obmanjivao svakoga. Naprotiv, uprkos konkurentskom odnosu između ekonomskih aktera, tržište podrazumeva iskrenost i otvorenost njegovih učesnika, $u$ pogledu ispunjavanja preuzetih obaveza, ali i očekivanja da će identičan odnos imati i drugi ekonomski učesnici. Upravo zbog toga, poverenje između ekonomskih subjekata, koje je uvek igralo značajnu ulogu u društveno-ekonomskom razvoju, najpotpunije se manifestuje upravo u tržišnoj ekonomiji. Kako ističe Aroww $(1972,357)$, svaka komercijalna operacija u sebi sadrži značajne elemente poverenja, posebno ako je za njenu realizaciju potreban određeni vremenski period. U skladu sa navedenim stavom, ovaj autor smatra da se znatan deo ekonomske zaostalosti u svetu može objasniti odsustvom uzajamnog poverenja.

Budući da se radi o najkonkretnijoj i najadekvatnijoj suštini problema poverenja, za potpunije poznavanje prirode ove neformalne institucije bitna je ekonomska analiza njene suštine. Pri tom, potrebno je naglasiti da poverenje nije sinonim za uobičajeno shvatanje dobrog odnosa prema čoveku. Kada govorimo o poverenju, potrebno je imati $u$ vidu da se ne radi o poverenju prema "čoveku kao takvom", već prema njegovim mogućnostima, sposobnostima, veštinama, moralnim karakteristikama itd. U tom smislu, potrebno je imati u vidu da karakteristike kao što su: tačnost, poštenje, svojstvo "držanja reči", predstavljaju svojevrsnu moć, a ne samo moralna svojstva (poslovni partner može da bude dobar prijatelj, a da pri tom hronično kasni, čime ugrožava poslovanje).

Kao ekonomska kategorija, poverenje podrazumeva odnose između ekonomskih subjekata, pri čemu jedna od ugovornih strana, na osnovu ocene moralnih i poslovnih svojstava druge strane, isključuje, u izvesnoj meri, mogućnost njenog oportunističkog ponašanja. Kao što je navedeno, različiti ekonomski subjekti, stupajući u međusobne poslovne odnose u uslovima neizvesne budućnosti, prinuđeni su da grade svoje odnose na izvesnom međusobnom poverenju. Zato se, figurativno govoreći, može reći da poverenje predstavlja "kiseonik", neophodan za normalno odvijanje poslovnih aktivnosti.

U savremenim uslovima privređivanja, poverenje ima sve veću ulogu ne samo $u$ okviru nacionalne ekonomije, već i u širim, međunarodnim relacijama. $\mathrm{O}$ tome koliko je poverenje značajno i u međunarodnoj ekonomiji govori činjenica da je jedna od tema Svetskog ekonomskog foruma u Davosu 2003. godine bila "Izgradnja poverenja". I to je pokazatelj da se poverenje danas sve više definiše kao osnova sistema ekonomske saradnje i na globalnom planu. O značaju poverenja, kao jednog od bitnih faktora ekonomskog ponašanja i ekonomske uspešnosti, takođe govore i mnogobrojna iskustva iz perioda finansijske krize 2008. godine. U antikriznim programima niza razvijenih zemalja fokus je staviljen na mere koje treba da rezultiraju povećanjem poverenja između vlade, banaka i dužnika. U Srbiji, na primer, zbog potrebe da se povrati poverenje $u$ finansijski sektor, akcenat je stavljen na povećanje visine štednog uloga za koji garantuje država.

Značaj faktora poverenja, kao principijelnog uslova uspešnog funkcionisanja tržišne ekonomije i ekonomskog razvoja, posebno se ispoljava tokom sprovođenja veoma kompleksnih društvenoekonomskih transformacija koje, $\mathrm{u}$ privredama $\mathrm{u}$ tranziciji, u ekonomskom smislu, treba da rezultiraju uspostavljanjem tržišnog sistema. Корнаи (2003) smatra da stepen prisustva ovog faktora $u$ društvu i ekonomiji omogućava da se lakše shvate uzroci uspeha i neuspeha u zemljama $u$ tranziciji. Nisu retke 
ni ocene (Стиглиц, 2001) da je nedostatak poverenja i uništavanje društvenog kapitala jedan od važnih uzroka za mnoge neuspehe reformskih procesa $u$ postsocijalističkim zemljama.

U okviru svog koncepta postindustrijskog društva, Fukuyama $(1999,129)$ naglašava da je ostvarivanje nekih od ključnih zadataka ekonomskog života, kao što je dobrobit nacije i njena konkurentska sposobnost, uslovljeno nivoom poverenja koje je prisutno $\mathrm{u}$ datom društvu. On poverenje tretira kao očekivanja, uspostavljena u okviru jednog društva, da će se članovi toga društva ponašati ispravno i pošteno, manifestujući spremnost za uzajamnu pomoć, u skladu sa opšteprihvaćenim normama. Poverenje sa kojim pojedinac računa, oslanja se na očekivanje da, iz njegove ranjivosti, partner neće izvlačiti sopstvene koristi pri postojanju takvih mogućnosti.

Drugim rečima, poverenje je svojevrsna prezumpcija integriteta $i$ iskrenosti u odnosima unutar određenog kruga partnera. Reč je o neizvesnim, ali očekivanim, načinima delovanja partnera. Integritet, formiran na osnovu prethodnog ponašanja, vodi ka stvaranju poverenja tokom narednih aktivnosti, što opravdava prihvatanje prezumpcije integriteta $\mathrm{u}$ odnosima sa njim. Istovremeno, poverenje je rezultat određene aktivnosti drugih, koji utiču na izbor pojedinaca, kada je pojedinac dužan da deluje na način koji je poznat kao delovanje drugih (Ostrom, 1998).

Uloga poverenja $\mathrm{u}$ društveno-ekonomskom životu je višestruka. Ono doprinosi većoj efikasnosti tržišne ekonomije, uspešnijem socijalnom partnerstvu i demokratskoj stabilnosti, utiče na lično zadovoljstvo $i$ optimističku percepciju budućnosti, pa, na taj način, podstiče i ekonomski rast. Nekoliko je aspekata posredstvom kojih visok nivo poverenja utiče na ekonomsku uspešnost i na ekonomski rast i razvoj:

- ostvaruje se intenzivnija razmena informacija, zahvaljujući čemu se olakšava koordinacija interesa ekonomskih aktera i uspostavlja punija saradnja u inovacionoj sferi;

- smanjivanjem stepena neizvestnosti u budućnosti smanjuju se rizici koji prate realizaciju krupnih investicionih projekata, kao i pretnje od oportunističkog ponašanja;
- smanjuju se transakcioni troškovi monitoringa i kontrole, troškovi zaštite prava vlasništva, što doprinosi smanjenju opterećenja pravnog sistema i povećanju njegove pravne sposobnosti.

Na Slici 1 ilustrovani su mogući pravci uticaja poverenja na neke od ključnih faktora, kao što su investicije, ljudski kapital, upravljanje, transakcioni troškovi, kolektivno organizovanje i delovanje, koji determinišu ekonomsku uspešnost i privredni rast.

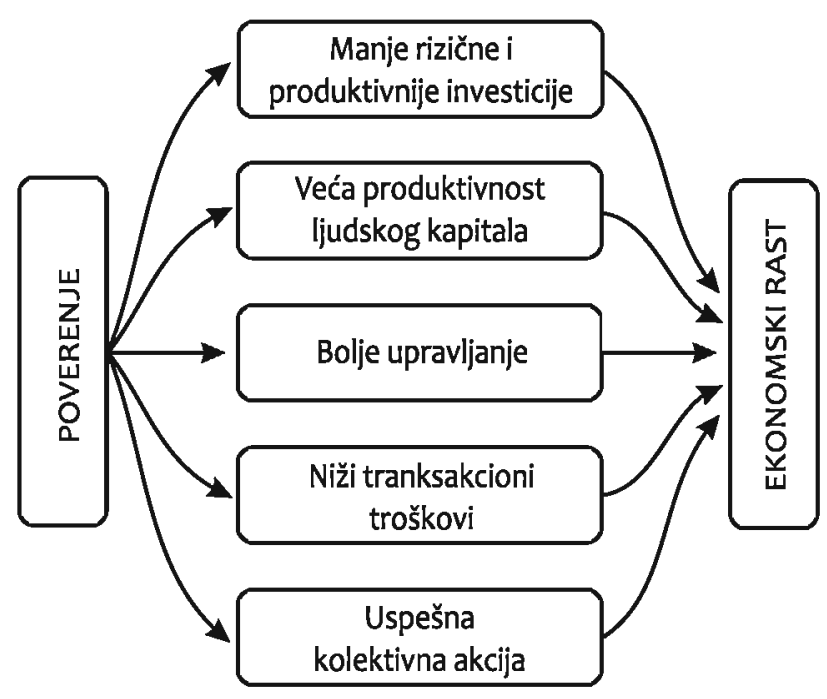

Slika 1 Uticaj poverenja na ekonomski rast

U savremenim uslovima, odnosi poverenja su važna pretpostavka uspostavljanja dugoročnih ekonomskih veza $\mathrm{i}$, idući dalje od interakcije između kompanija, počinju da vrše sve veći uticaj na ekonomske odnose na makro nivou. Aktuelne su i aktivnosti uspostavljanja poverenja između država, njihovih rukovodstava, između ekonomskih subjekata različitih zemalja i sl.

Imajući u vidu da se poverenje, $u$ suštini, bazira na reputaciji kompanija, a ne na analizi konkretnih ugovornih uslova, tone znači da dolazi doograničavanja konkurencije, jer je reputacija, pre svega, izvesnost koja je rezultat prethodnih ponašanja i koja podrazumeva da će njen nosilac i u budućnosti da se ponaša u skladu sa prethodno stečenim ugledom (reč je o pozitivnoj reputaciji). Poverenje koje se bazira, u većoj meri, na 
reputaciji privrednog subjekta, predstavlja jedan od bitnih instrumenata konkurentske borbe, pa se može reći da je u pitanju "konkurencija reputacija".

Takođe, potrebno je detaljnije razmotriti suštinu i sadržaj samog socijalno-ekonomskog fenomena kao što je "institucija poverenja". Problem formiranja efikasne institucije poverenja najjasnije je izražen u okviru institucionalne ekonomske misli. U radovima institucionalista, jasno je artikulisan stav da visok nivo poverenja omogućava firmama i pojedincima da se značajno smanji pretnja oportunizma, reši problem neizvesnosti i smanje troškovi monitoringa i kontrole, koji su neizbežni u uslovima nepotpunih ugovora. Pri tom, poverenje podstiče kontinuiranu razmenu informacija, čime se, usaglašavanjem različitih interesa privrednih subjekata, sprečavaju značajni troškovi zaštite prava vlasništva.

Jednom uspostavljen nivo poverenja menja se tokom odvijanja uzajamnih odnosa između ekonomskih strana, što ukazuje na to da je formiranje odnosa poverenja dinamički proces, skopčan sa nizom utrošaka. U pitanju su transakcioni troškovi, koji su rezultat prikupljanja informacija o partnerima, povremeni troškovi zbog očuvanja poslovnih veza sa partnerima i sl. Za ovu vrstu troškova možemo reći da predstavljaju investicije $\mathrm{u}$ odnose poverenja. Dinamička priroda poverenja ispoljava se u postupno formiranoj reputaciji dostojnoj poverenju partnera. $\mathrm{Za}$ reputaciju se kaže da predstavlja nematerijalnu aktivu, čija se vrednost određuje merom pouzdanosti sa kojom partneri mogu da ocene buduća ponašanja ekonomskog agenta. U tom smislu, reputacija se može posmatrati kao implicitni ugovor (Furubotn \& Richter, 2000), koji za organizaciju predstavlja vredan kapital. Naime, reputacija omogućava firmi da štedi na troškovima jer isključuje sastavljanje detaljnih ugovora, kao i usaglašavanje $\mathrm{u}$ pogledu precizne podele nadležnosti i odgovornosti. S druge strane, ukoliko partneri prihvataju reputaciju poštenog ponašanja, kao neku vrstu ideala, uspostavlja se ravnoteža koja može da ima višestruki i mnogo širi društveni značaj. U tom smislu, na reputaciju treba gledati kao na jedan od izvora poverenja.

\section{OSNOVNI TIPOVI POVERENJA}

Tipologija poverenja, kao jedne od najvažnijih neformalnih institucija, može se izvršiti po više kriterijuma. Pri tome, pažnja se najčešće usmerava na razlikovanje interpersonalnog i institucionalnog poverenja (poverenje ljudi $u$ društvene institucije i njihove predstavnike). Takođe, pravi se razlika između vertikalnog i horizontalnog poverenja. Pod vertikalnim se podrazumeva poverenje prema društvenim organizacijama (vladi, zakonodavnim organima, crkvi, sindikatima i sl.), a pod horizontalnim poverenje između ljudi. Prilikom ukazivanja na različite vidove poverenja, naglašava se da, ako je lično poverenje svojevrsni fundament svakog društva, institucionalno poverenje je osnova funkcionisanja složeno organizovanog društva, u kojem postoje različite organizacije, koje generišu i podržavaju pravila igre. U ovom radu, naglasak se stavlja, upravo, na institucionalno poverenje-poverenje pojedinaca prema društvenim institucijama, njihovim predstavnicima, institucionalnim praksama i procedurama.

Za poverenje koje karakteriše ne samo odnose između subjekata koji imaju kontinuiranu komunikaciju, već i odnose u sistemu kao celini, govori se da predstavlja depersonalizovano poverenje, tj. opšte (socijalno) poverenje. Tako uspostavljeno poverenje predstavlja važan kvalitet građanskog društva, što omogućava kvalitetnije integrisanje građana u okviru zajedničkih socijalnih incijativa. Zahvaljujući toj bitnoj socijalnoj vrednosti, formiraju se tolerantniji odnosi između ljudi, što funkcionisanje društva čini uspešnijim. Zbog toga, neki autori (Ostrom, 1998; Uslaner, 2002; Uslaner \& Badescu, 2002) ukazuju na to da razvoj opšteg poverenja predstavlja fundamentalni problem, istovremeno i značajno opredeljenje svakog društva. U ovom kontekstu, kao bitno, nameće se pitanje o izvorima opšteg poverenja. Posebno se razmatra uticaj na poverenje, kako dobrovoljnih udruženja, asocijacija (formalnih i neformalnih) i sličnih struktura, tako i države. Može se primetiti da je uticaj različitih dobrovoljnih udruženja dvosmislen, što je povezano sa njihovim karakterom. S tim u vezi, ne može se očekivati rast socijalnog poverenja kada je delatnost pojedinih asocijacija usmerena na izvlačenje pogodnosti za njihove članove na račun ostalog dela društva. Tako, na primer, formiranje kartela dobavljača, sa ciljem 
podizanja cena, kod potrošača samo pojačava sumnju u odnosu na njih.

U mnogim istraživanjima (Hall, 1999; Kaase, 1999) ističe se da je opšte poverenje determinisano načinom funkcionisanja političkih i sudskih institucija. Pri tom se ukazuje na odnos između poverenja $u$ takve institucije (institucionalno poverenje) i opšteg poverenja, čiji uzročno-posledični odnosi imaju dvostruku prirodu. S jedne strane, formiranju opšteg poverenja doprinose optimistički odnosi prema postojećim političkim institucijama, a opšte poverenje, s druge strane, pretpostavka je veće efikasnosti državnih institucija. Potpunije razjašnjenje njihove uloge u razvijanju opšteg poverenja omogućava bolju percepciju strukture institucija, sa posebnom pažnjom na one koje imaju zapaženiju ulogu u svakodnevnom životu građana. Procene građana o performansama ovih institucija, s jedne strane, i o pravičnosti njihovih odluka i aktivnosti, s druge strane, karakterišu dva ključna aspekta institucionanog poverenja: prema efikasnosti institucija i prema njihovoj pravičnosti. Pri tome, odnos prema aktivnostima institucija na mikro nivou umnogome se prenosi i na makro nivo. Na taj način, institucionalno poverenje značajno utiče na ukupan kredibilitet društva kao celine, kao i njegovih gradivnih elemenata.

Za formiranje ukupnog poverenja u društvu značajna je uloga državnih institucija. Prednost institucionalnog koncepta sastoji se $\mathrm{u}$ tome što se lično iskustvo $\mathrm{i}$ poverenje ne ignorišu, već se uklapaju u opštu sliku poverenja kao socijalnog fenomena. Ta koncepcija je u skladu sa onim shvatanjima (Knack \& Keefer, 1997) po kojima zemlje sa manjom socijalno-ekonomskom diferencijacijom i sa ravnomernijom raspodelom dohotka imaju viši nivo ukupnog (opšteg) poverenja.

Ne dovodi se u sumnju da poverenje ima važnu ulogu $\mathrm{u}$ eliminisanju opasnosti od oportunizma, čime se određuje karakter saradnje i utiče na forme organizacije i nivo transakcionih troškova. Zbog toga se poverenje sve češće razmatra u svojstvu bitnog faktora ekonomske uspešnosti, kao i ekonomskog razvoja (Дяско, 2003б, 42-58). Posebna pažnja usmerava se na ulogu poverenja u sprovođenju društveno-ekonomskih transformacija, sa naglaskom na one procese koji su povezani sa izgradnjom tržišne privrede, što omogućava da se na bolji način shvate razlozi za uspeh i neuspeh zemalja u tranziciji. U tom smislu, Стиглиц (2001) apostrofira nedostatak poverenja i uništenje socijalnog kapitala kao ograničavajuće faktore u sprovođenju reformi.

Jedan od najsloženijih i najvažnijih oblika poverenja predstavlja poverenje prema institucijama, a pre svega prema državi. Pri tome, institucionalno poverenje može se okarakterisati kao obezličeno poverenje $u$ odnosu prema zvanično ustanovljenim pravilima, normama i principima. $\mathrm{U}$ tom kontekstu, poverenje $\mathrm{u}$ pravila projektovano je kao poverenje $\mathrm{u}$ organizacije koje sprovode ta pravila. Istovremeno, poverenje $\mathrm{u}$ organizacije projektuje se na njihovo rukovodstvo. Analiza institucionalnog poverenja, $u$ čijoj strukturi je poverenje $u$ državu, organizacije $i$ njihove predstavnike, od ključnog je značaja. S obzirom na prirodu institucionalnog poverenja, ono ima svoju specifičnost u poređenju sa međuljudskim poverenjem. Pod međuljudskim poverenjem podrazumeva se, pre svega, poverenje između ljudi koji se lično ne poznaju (u institucionalnoj literaturi takav vid poverenja naziva se poverenjem, uopšte, za razliku od personalizovanog). Posebno se identifikuje odnos između ova dva vida poverenja. U slučaju institucionalnog poverenja, koje se ne odnosi na konkretna lica, govori se o sposobnosti (kapacitetu) nekog sistema pravila i organizacija.

Imajući u vidu da je ono rezultat odnosa ne prema ugovorima, zakonima, organizacijama, već prema licima koja su odgovorna za sprovođenje odgovarajućih pravila, može se zaključiti da institucionalno poverenje u sebi sadrži bitnu personalnu komponentu. Drugim rečima, poverenje prema institucijama predstavlja formu poverenja koje je rezultat odnosa između ljudi. $\mathrm{U}$ tom smislu, ispravno je govoriti o institucionalnom poverenju kao o poverenju $\mathrm{u}$ institucije koje, $\mathrm{s}$ jedne strane, stvaraju sami ljudi, a s druge, neposredno utiču na sadržaj tih odnosa. Pri tom, institucije imaju značajan uticaj ne samo na karakter međuljudskih odnosa, već $\mathrm{i}$ na samu čovekovu individualnost, na formiranječoveka kao ličnosti u samom radnom procesu. Kada društveno organizovani rad pruža mogućnost pojedincu da samostalno donosi odluke, preuzima inicijativu i odgovornost, $u$ procesu zajedničkog rada se u punoj meri otkriva njegov potencijal. U protivnom, postoji rizik od njegove degradacije do nivoa jednostavnog dodatka mašini, pretvarajući ga u bezličnog subjekta. 
Kada jedan čovek veruje drugome, on od njega očekuje povoljno, u krajnjoj meri, nediskriminatorno ponašanje, pa i ne postoji potreba da se takva transakcija formalno kontroliše (Корнаи, 2003, 5). U tom smislu, poverenje postaje svojevrsna prezumpcija savesnosti u odnosima između partnera. Poverenje počiva na stavu da iz njegove moguće slabosti partner neće izvlačiti vlastite koristi, već da će se ponašati iskreno, uz spremnost za uzajamnu pomoć, u skladu sa opšteprihvaćenim pravilima inormama. Pri tome, u mehanizmu poverenja značajnu ulogu igra stav da su subjekti spremni ne samo da formalno prihvataju pravila, već i da ih poštuju, što ukazuje na to da je poverenje $u$ institucije determinisano i ocenom stepena njihove usklađenosti sa očekivanjima subjekata, tj. kako su one izgrađene sa stanovišta njihove efikasnosti i pravičnosti. Otuda stav da se institucionalno poverenje uspostavlja na potpuniji način u slučaju kada su institucije uređene efikasno i pravično.

Pitanje poverenja $u$ državu i njene institucije ima posebnu specifičnu težinu, s obzirom na njenu ulogu kreatora i garanta institucionalnog ambijenta. Nivo poverenja $u$ državu opredeljen je sa dve bitne komponente. Jedna od njih odnosi se na to koliko državne institucije omogućavaju efikasno odvijanje ekonomskih aktivnosti (bez obzira na to da li je u pitanju stvaranje neophodnih uslova za efikasnu konkurenciju, ili učešće same države u ekonomskom procesu). Druga komponenta odnosi se na pravičnost samih institucija (formalnu sadržinu ustanovljenih pravila, mehanizme njihovog razvijanja i usvajanja, ustrojstvo organizacije). Naime, bitno je da važeće državne institucije budu efikasne $u$ ispunjavanju glavnih ciljeva ekonomije, a da, s jedne strane, na najbolji mogući način odgovaraju zahtevima pravičnog uređenja, a s druge strane, da doprinesu postizanju maksimalne ekonomske efikasnosti. Potrebno je naglasiti da su oba navedena uslova uzajamno povezana i međusobno uslovljena $\mathrm{s}$ obzirom na to da:

- bez ekonomske efikasnosti, pri definisanju državne ekonomske politike, nije moguće ostvariti željeni materijalni rezultat, koji će da omogući povećanje kvaliteta života ljudi;

- ignorisanjem principa pravičnosti bilo bi otežano ostvarivanje željene ekonomske efikasnosti.

\section{INSTITUCIONALNO POVERENJE I EKONOMSKA USPEŠNOST}

Institucionalna struktura nacionalne ekonomije, koju sačinjava sveukupnost formalnih i neformalnih institucija i mehanizama njihovog poštovanja i ostvarivanja, predstavlja bitan faktor efikasnosti alokacije resursa i ekonomskog razvoja. Njihova uloga neophodna je za rešavanje relevantnih problema, ne samo koordinacije aktivnosti u uslovima ograničene racionalnosti aktera, već i distributivnih konflikata, s obzirom na to da ekonomski subjekti slede vlastite ekonomske interese. Uloga institucija, kako formalnih, tako i neformalnih, manifestuje se $\mathrm{u}$ tome što, svojim efikasnim delovanjem, bitno doprinose redukovanju troškova transakcije, čime pozitivno utiču na uspešnost odvijanja ekonomskih aktivnosti.

U okviru skupa neformalnih institucija, značajno je naglasiti ulogu istorijskog i kulturološkog nasleđa, ideologije i sl. kao bitnih faktora koji doprinose uspostavljanju i razvijanju moralnih normi. Pri tome, moralne norme su značajne jer podržavaju vrednosni sistem društva, a istovremeno, utiču na uspostavljanje i ostvarivanje vladavine prava u društvu. Razvojem vrednosnog sistema društva uspostavljaju se povoljniji uslovi za ostvarivanje poverenja između učesnika u ekonomiji, čime se, u uslovima asimetričnih informacija, olakšava proces ekonomske razmene. $\mathrm{Na}$ taj način, podržava se uspostavljanje efikasnog skupa formalnih institucija, tj. sistema zakona i pravila kojim se strukturiraju društvene interakcije i ekonomska razmena, što je bitna pretpostavka za efektivno i efikasno odvijanje ekonomskih aktivnosti.

Istovremeno, takvi odnosi doprinose rastu poverenja u vladine institucije, što je veoma značajno s obzirom na komplementarnost između postojećeg nivoa poverenja i efikasnosti vlade. Kada je poverenje u vladine institucije na niskom nivou, pritisak na državne službenike da kvalitetnije i odgovornije vrše svoje dužnosti je slab. Loše vladanje smanjuje poverenje, što uzrokuje inferiorne ekonomske rezultate. Nasuprot tome, $\mathrm{u}$ uslovima visokog nivoa društvenog poverenja, može se uspostaviti jači javni pritisak na državne službenike, što ima za rezultat efikasnije javno upravljanje, kao bitnu pretpostavku poslovnog ambijenta koji je podsticajan za odvijanje ekonomskih aktivnosti. To 
ima poseban značaj u kontekstu borbe protiv korupcije, s obzirom na to da je stalni javni nadzor nad državnim zvaničnicima najefikasnije sredstvo koje ih obavezuje da se vladaju u skladu sa definisanim pravilima. $\mathrm{Na}$ taj način, povećava se poverenje $u$ državne institucije pa je, samim tim, povećana pouzdanost i efikasnost formalnih institucionalnih okvira.

Opšte poverenje ostvaruje uticaj na ekonomske učinke posredstvom makropolitičkih kanala, pre svega zahvaljujući kvalitetu institucija. U tom smislu, zemlje u kojima su razvijenije formalne institucije, koje efektivno štite svojinska prava, poštovanje ugovora i sprovođenje zakona, imaju povoljnije uslove za uspostavljanje i unapređivanje uzajamnog poverenja. To upućuje na zaključak da, pod istim ostalim uslovima, veći nivo poverenja pozitivno deluje na ekonomsku uspešnost $\mathrm{i}$ na stopu ekonomskog rasta.

Analiza ekonomske razmene ima u vidu transakcionu racionalnost, pri čemu se racionalnost izbora bazira na razlici transakcione dobiti i transakcionih troškova. Da bi se postiglo racionalno funkcionisanje sistema, potrebna je kontrola troškova od strane institucija tokom uspostavljanja i sprovođenja ugovornog odnosa. Zbog toga, aktivnost uspostavljanja institucionalnog okvira kojem će se verovati podrazumeva određeni iznos troškova koji su neizbežni i poželjni (Furubotn \& Richter, 2008). Zapravo, takav institucionalni okvir doprinosi uspostavljanju poverenja, koje pozitivno utiče na ekonomsku uspešnost, što se odražava kroz pozitivne ishode $\mathrm{u}$ slučaju manifestovanja kolektivnih problema. Na taj način, omogućava se bolja kooperacija, čiji su krajnji ishod niži transakcioni troškovi, a samim tim i veća tržišna efikasnost. Istovremeno, socijalno poverenje redukuje troškove sprečavanja oportunističkog ponašanja, pa društvo, umesto da investira $u$ monitoring i nadzor, usmerava resurse ka produktivnim investicijama.

Poverenje između ekonomskih aktera, kao i institucionalno poverenje, utiče na nivo ekonomske uspešnosti, samim tim i na kretanje GDP per capita. Naime, poverenje kao rezultat ponovljene interakcije između ekonomskih partnera, odražava se na širenje ekonomskih aktivnosti. Istovremeno, poverenje kao neformalna institucija utiče na razvoj formalnih institucija koje, svojim povratnim uticajem, promovišu poverenje koje ima pozitivno dejstvo na povećanje nivoa ekonomske uspešnosti. Pojedinci koji uspešno sarađuju, čime učvršćuju poverenje, razvijaju neformalnu instituciju dogovora, koja je od izuzetne važnosti u slučaju potrebe rešavanja eventualnih nesporazuma koji bi nastali prilikom raspolaganja zajedničkim resursima.

Ukazivanje na značaj fenomena poverenja omogućava da se, u uslovima asimetričnih informacija, nepotpunosti ugovora, per se neizvesne budućnosti, razume način očuvanja vitalnosti ekonomije. Asimetričnost informacija, kao situacija u kojoj je jedna strana bolje informisana od druge i svesna svoje informacione prednosti, rezultira moralnim rizikom, ili moralnim hazardom, u pogledu mogućnosti korišćenja svoje prednosti. Širenjem posledica različite informisanosti ekonomskih agenata dolazi do tzv. negativne selekcije, izražene $\mathrm{u}$ lažnom predstavljanju privatnih informacija, $u$ cilju zaključivanja ugovora koji će za njega biti korisniji, a koji rezultira neefikasnim funkcionisanjem tržišta. Manje informisana strana prinuđena je da, radi osiguranja transakcije, troši sredstva na prikupljanje dodatnih informacija, kao i na formulisanje složenijih i potpunijih ugovora. Međutim, poverenje smanjuje potrebu za takvom vrstom rashoda.

U uslovima asimetričnih informacija i nepotpunih ugovora, poverenje predstavlja svojevrsni katalizator ekonomskih aktivnosti. Njegova uloga je značajna, kako u pogledu predugovornih, tako i u slučaju postugovornih asimetričnih informacija. Asimetričnost $\mathrm{u}$ raspolaganju informacijama dovodi do negativne selekcije, kao oblika predugovornog oportunizma, na osnovu čega prodavac može da ostvari kratkoročnu korist. Tako, usled nepotpunih informacija, dolazi do neefikasnog funkcionisanja tržišnog mehanizma. Uspostavljanje odnosa poverenja između prodavca i kupca predstavlja jedan od načina za sprečavanje takvog razvoja situacije. Poverenje, $u$ datom slučaju, znači očekivanje kupca da prodavac neće da koristi njegovu manju informisanost radi prodaje robe po višoj ceni. Takvo poverenje može se stvarati iz različitih izvora: iz ranijih poslova, koji su rezultirali odgovarajućom reputacijom, do procene kupca o zainteresovanosti prodavca za dugoročni razvoj svog biznisa, na šta je teško računati pri obmanjivanju 
kupaca. Druga mogućnost bila bi detaljizacija kupoprodajnog ugovora, sa specifikacijom parametara kvaliteta robe i obaveza prodavca u slučaju da prodata roba ne odgovara utvrđenim parametrima. Ta opcija podrazumeva dodatne transakcione troškove, kako pri razradi takvog ugovora, tako i pri prinuđivanju prodavca da ispuni svoje obaveze, što dodatno opterećuje poslovnu transakciju.

Takođe, $\mathrm{u}$ poznatom odnosu principal-agent, $\mathrm{u}$ uslovima njihove različite postugovorne informisanosti o predmetu upravljanja, postoji potencijalna pretnja od pojave moralnog rizika $\mathrm{u}$ vidu postugovornog oportunizma. On se pojavljuje pri realizaciji ugovora kada partner, koji je bolje informisan, maksimira svoje blagostanje na račun drugoga. Takva mogućnost se amortizuje sa rastom poverenja između principala $\mathrm{i}$ agenta. Poverenje $\mathrm{u}$ datom slučaju podrazumeva, s jedne strane, očekivanje principala da agent neće da zloupotrebi svoju bolju informisanost, a s druge strane, očekivanje agenta da će njegov savestan rad biti adekvatno nagrađen od strane principala. Izvori takvog poverenja mogu biti različiti: reputacija agenta, lični odnosi i sl. Mogući pristup rešavanju problema principal-agent na osnovu korišćenja takozvanih stimulativnih ugovora faktički predstavlja žal za racionalnim poverenjem. $\mathrm{O}$ tome da je idealan ugovor za menadžera nemoguć govori činjenica da nema potpuno racionalnog poverenja između vlasnika i menadžera. Međutim, opravdano je i očekivanje optimalnog nivoa poverenja među njima.

$\mathrm{U}$ nastojanjima da se proces društveno-ekonomskog razvoja ubrza, što podrazumeva razvijenei konzistentne institucije, često se pribegava transplantaciji ili uvozu institucija. Reč je o transferu institucija, koje su formirane $\mathrm{u}$ jednoj, institucionalno razvijenijoj sredini, u drugu, manje razvijenu (Полтерович, 2001, 24-50). Kao što pokazuje praksa, uključujući i srpsku, ovaj vid pozajmljivanja često se pokazuje neuspešnim. Odgovor na pitanje zbog čega se ovo dešava moguće je pronaći $\mathrm{u}$ institucionalnoj koncepciji poverenja. Zapravo, nivo poverenja $u$ transplantirane ekonomske institucije zavisi, s jedne strane, od ocene njihove efikasnosti $u$ zemlji primaoca, a s druge strane, od ocene implikacije državne institucije na socijalnu pravdu u društvu, što zavisi od načina na koji se određene institucije implementiraju. Primera radi, poverenje u privatizaciju stanova razlikuje se od poverenja $u$ privatizaciju privrednih i infrastrukturnih subjekata. Neadekvatan odnos tokom masovne privatizacije rezultirao je odsustvom efikasnog sistema zaštite prava vlasništva, pa je, umesto rasta poverenja $u$ instituciju privatnog vlasništva, došlo do obrnute situacije, a naneta je i šteta poverenju u srodne institucije, posebno u sudstvo.

Negativna ocena efekata transplantacije nove sistemske institutcije predstavlja, sa stanovišta socijalne pravde $\mathrm{u}$ društvu, katalizator masovnih oportunističkih aktivnosti, kako u odnosu prema ovoj, tako i prema drugim institucijama. Taj oportunizam može se manifestovati zahtevom za takvim institucijama koje ne odgovaraju oficijelnoj ligici reformi, što, u skladu sa tom logikom, smanjuje kapacitet uvedenih instituta. To pokazuje da, što je manje poverenje u nove institucije, veći su troškovi uvođenja i podrške njihovom opstanku, pa su i transakcioni troškovi njihovog korišćenja visoki. Na koji način se nisko poverenje manifestuje u visokim transakcionim troškovima, najjasnije se može videti iz poteškoća u realizaciji prava vlasništva.

Ekonomska praksa je potvrdila da odsustvo efikasnih mehanizama zaštite svojinskih prava i ugovornih obaveza povećava rizik na tržištu kapitala, što dovodi do paralize investicione i inovacione aktivnosti na mikro nivou. U tom smislu, North $(2003,77)$ smatra da nesposobnost društva da obezbedi da se ugovori sprovode efikasno, i uz niske troškove, kvalitativno predstavlja najvažniji uzrok stagnacije i zaostalosti zemalja Trećeg sveta. Ključne indikatore zaštićenosti prava vlasništva i ugovornih obaveza čine efikasnost sudskog sistema, poštovanje zakona, nivo korupcije, rizik konfiskacije, rizik kršenja ugovora. Nesporno je da država ima ključnu ulogu u sprovođenju vlasničkih prava, putem regulacije, nadzora i sudsko-pravnih procedura. Međutim, uporedo sa zahtevom za usavršavanje pravnog sistema, poslednjih godina sve više se ukazuje na potrebu povećanja nivoa poverenja između poslovnih partnera (Мильнер, 1997; Дяско, 2003a).

Međusobno poverenje ekonomskih subjekata i jasna specifikacija vlasničkih prava rezultiraju manjom potražnjomzajavno-pravnimiprivatnimmehanizmima zaštite svojinskih prava i ugovornih obaveza. Naime, što je veće uzajamno poverenje poslovnih partnera, 
to je manje sudskih procesa. Na taj način, smanjuje se pritisak na pravosuđe i ubrzavaju se pravne procedure, što dodatno jača poverenje $u$ pravosuđe $i$ birokratski mehanizam, smatra Корнаи $(2003,8)$. Krajnji ishod je nesporan: što je viši nivo poverenja između poslovnih partnera, to su niži transakcioni troškovi. Istovremeno, uštede $u$ sadašnjim transakcionim troškovima mogu se ostvariti na račun transakcionih troškova koji su nastali u fazi izgradnje odnosa poverenja. Zbog toga je potrebno takve troškove uzeti u obzir prilikom analize ekonomske uloge poverenja (Ляско, 2003б).

Međutim, svakom nivou poverenja partnera odgovara i adekvatan nivo uzajamne kontrole. Zapravo, održavanje odnosa poverenja ne podrazumeva i potpuno odricanje od monitoringa i kontrole. Pre se može govoriti o poverenju koje se oslanja na odnose kontrole. Počev od dodatnih mehanizama za praćenje i sankcionisanje, kada je poverenje između partnera razrađeno i pokazano, znači da prethodno poverenje nije ni postojalo. Kada je partner izvan okvira kontrole, održavajući pouzdan odnos, on time šalje svojim partnerima signal da su odnosi uzajamnog poverenja do određenog stepena iscrpljeni i da je potrebno da budu ponovo izgrađeni (Дяско, 2003a). Istovremeno, odnosi poverenja su veoma raznovrsni $i$, $u$ pojedinim slučajevima, mogu da imaju različitu ulogu u društvu. Tako, od odnosa poverenja između učesnika kriminalnih grupa, između davaoca i primaoca mita, štetu imaju drugi članovi društva. Na primeru poznate zatvorenikove dileme zaključujemo da, što je veći stepen poverenja između prestupnika, tim je teže da pravosudni sistem uspešno realizuje svoj zadatak.

Konceptualni stavovi o ulozi poverenja u ekonomskom razvoju dobili su svoju potvrdu u analitičkim modelima i statističkim posmatranjima. U nizu empirijskih istraživanja, identifikovana je korelacija između poverenja i ekonomskog rasta (Knack \& Keefer, 1997). Na bazi modela ravnotežnog rasta, potvrđeno je da društvu sa niskim nivoom poverenja preti zamka siromaštva (Zak \& Knack, 2001).

Kriza poverenja u domaćoj ekonomiji, koja se javlja još 1980-ih godina, u još većem stepenu se ispoljila tokom sprovođenja tranzicionih aktivnosti $u$ poslednje dve decenije. Orijentacija $u$ sprovođenju društveno-ekonomskih transformacija na uzak spektar mehanizama koordinacije nije pogodovala prevazilaženju krize poverenja i dovela je do protivrečnih rezultata. Ti rezultati mogu da posluže kao ilustracija toga do čega u ekonomskom razvoju dovodi nedostatak poverenja. Uništavanje starog socijalnog i organizacionog kapitala, bez odgovarajućeg naglaska na stvaranje novog, imalo je značajnog uticaja na ekonomske i društvene neuspehe $u$ dosadašnjem periodu tranzicije, na šta ukazuje i Стиглиц $(2001,114)$. Može se reći da su mnoge od suštinskih karakteristika domaće ekonomije posledica prilagođavanja njenih subjekata uslovima koje karakteriše nedostatak poverenja, kako u odnosima između firmi, tako i $\mathrm{u}$ odnosima sa državom. Primera radi, u određenom periodu tranzicije, u Srbiji je bila prisutna trampa, kao najjednostavniji oblik razmene, što je bilo uslovljeno, pored drugih ekonomskih i političkih razloga, nepoverenjem između poslovnih partnera.

\section{ZAKLJUČAK}

Brojne analize, kao i ekonomska realnost, pokazale su da je za uspešno funkcionisanje i stabilnost ekonomije značajno postojanje poverenja između ekonomskih aktera. Ekonomija, naime, zahteva ne samo adekvatnu institucionalnu uređenost, već i odgovarajuće socijalne relacije koje će doprineti širenju poverenja. $U$ društvima koja se nalaze $u$ procesu tranzicije, upravo je nedostatak poverenja u ekonomskoj, kulturnoj i političkoj sferi, bitna prepreka u izgradnji civilnog društva bez kojeg nema odgovorne vlade, samim tim ni ključne pretpostavke za političku i ekonomsku stabilnost.

Istovremeno, brojni problemi, kako ekonomski, tako i društveni, sa kojim se suočavaju zemlje u tranziciji, najčešće se objašnjavaju nerazvijenim institucijama i niskim nivoom poverenja. Istovremeno, iako sva odgovornost za brojna otvorena pitanja procesa tranzicijene može da bude delegirana nainstitucionalnu komponentu, ipak bi svaka analiza dosadašnjih efekata društveno-ekonomskih transformacija $u$ zemljama u tranziciji, u kojoj bi se zanemario bilo koji od ova dva faktora, rezultirala nepotpunim i jednostranim zaključcima. Otuda i ocene da nedostatak poverenja predstavlja jedan od uzroka neuspešnih reformskih 
procesa $\mathrm{u}$ bivšim socijalističkim zemljama. Istovremeno, u svim zemljama u kojima su sprovođeni konzistentniji reformski programi, na dosledniji način, znatno je podignut nivo opšteg poverenja, pa su svi akteri manifestovali punu spremnost da podržavaju reformske procese i da u njima aktivno participiraju. Krajnji ishod tako kreiranih i sprovođenih tranzicionih aktivnosti jeste veća ekonomska uspešnost ekonomskih aktera i dinamičniji ekonomski rast, što ukazuje na to da postoji pozitivna korelacija između društvenoekonomske stabilnosti i ekonomskog rasta, s jedne strane, i svih oblika poverenja $u$ jednom društvu, $s$ druge strane. Na bazi toga, formira se zaključak da je nivo poverenja $u$ jednom društvu indikator njegovog "zdravlja" i vitalnosti.

Ako posmatramo Srbiju, koju karakteriše duboka i dugotrajna ekonomska kriza (visok nivo zaduženosti zemlje i spoljnotrgovinskog deficita, rekordno visoka nezaposlenost i emigracija mladih i obrazovanih kadrova, osiromašenost stanovništva, deindustrijalizacija Zemlje), rasprostranjenost kriminala i korupcije, odustvo rešenosti da se jača institucionalni kapacitet društva i ekonomije, jasni su razlozi za to što je nepoverenje karakteristično za sve segmente našeg društva. Kada vlast nije spremna da kreira celovite i konzistentne reformske programe i da energičnije sprovodi obećane reforme, kada ne stvara institucionalni ambijent koji će podsticati ekonomske aktivnosti i ekonomski rast, logično je da će produkovati nove vidove nepoverenja $u$ društvu. $U$ takvim uslovima, male su mogućnosti za jačanje socijalnog poverenja, koje je ključni uslov za ostvarivanje punije društvene saradnje. Suprotan primer su zemlje $u$ kojima je tranzicija uspešnije sprovođena. Ti primeri pokazuju da se relativno brzo može izgraditi poverenje, kao ključni indikator socijalnog kapitala, što je bitna pretpostavka ekonomske uspešnosti i ekonomskog rasta i razvoja.

U Izveštaju Svetske banke za 2011. godinu naglašava se da je, čak i u zemljama u razvoju, moguće da se u okviru jedne generacije postigne zadovoljavajući nivo jačanja poverenja, uspešnija transformacija i izgradnja ekonomskih institucija, što je bitan garant za bezbednost i pravičnost građana. Međutim, to podrazumeva da rukovodeće strukture zemlje budu posvećene suštinskim institucionalnim reformama i da težište svoje ukupne aktivnosti usmere, pre svega, na jačanje institucionalnog kapaciteta zemlje, iz razloga što legitimnost institucija predstavlja garanciju stabilnosti privrede i društva, što je bitna pretpostavka veće ekonomske uspešnosti i bržeg rasta razvoja. Za uspešnu transformaciju bazičnih institucija bitno je jačanje društvenog i personalnog poverenja $u$ ključne društvene aktivnosti, koje za krajnji cilj imaju unapređivanje institucionalnog ambijenta. Stavovi do kojih smo došli u ovom radu, kojim se potvrđuje postojanje pozitivne korelacije između poverenja i institucionalne razvijenosti, s jedne strane, i ekonomske uspešnosti, s druge strane, ukazuju na neophodnost postojanja jasno formulisane strategije unapređivanja institucionalne infrastrukture privrede i društva, kao i sistema vrednosti društva, u okviru kojeg poverenje zauzima značajno mesto. Zbog svoje aktuelnosti, pitanja institucionalne infrastrukture i poverenja, kao determinante ekonomskog i društvenog razvoja, nesporno će biti predmet budućih istraživanja, kako bi se, naučno utemeljenim i metodološki validnim pristupom ovoj problematici, dao relevantan doprinos uspostavljanju privredno-sistemskog i društvenog ambijenta koji bi bio podsticajan za podizanje nivoa ekonomske uspešnosti privrede Srbije.

\section{ZAHVALNICA}

Ovaj rad deo je Projekta osnovnih istraživanja (br. 179015), koji finansira Ministarstvo nauke Republike Srbije.

\section{REFERENCE}

Aroww, K. J. (1972). Gifts and Exchanges. Philosophy and Public Affairs, 1(4), 343-362.

Coleman, J. S. (1990). Foundations of Social Theory. Cambridge, Massachusetts: The Belknap Press of Harvard University Press.

Fukuyama, F. (1999, October 1). Social Capital and Civil Society. Paper presented at the IMF Conference on Second Generation Reforms, The Institute of Public Policy, George Mason University.

Fukuyama, F. (2002). Social Capital and Development: The Coming Agenda. SAIS Review, XXII(1), 23-37. 
Фукуяма, Ф. (2004). Доверие. Социальные добродетели и путь к процветанию. Москва, Россиа: ООО Издательство АСТ : ЗАО НПП Ермак.

Furubotn, E. G., \& Richter, R. (2000). Institutions \& Economic Theory: The Contribution of The New Institutional Economics. Michigan, USA: The University of Michigan Press.

Furubotn, E. G., \& Richter, R. (2008). Institutions \& Economic Theory. Michigan, USA: The University of Michigan Press.

Hall, P. (1999). Social Capital in Britain. British Journal of Political Science, 29(3), 417-464.

Kaase, M. (1999). Interpersonal Trust, Political Trust and Noninstitutionalised Political Participation in Western Europe. West European Politics, 22(3), 1-22.

Knack, S., \& Keefer, P. (1997). Does social capital have an economic payoff? A cross-country investigation. Quarterly Journal of Economics, 112(4), 1251-1288.

Корнаи, Я. (2003). Честность и доверие в переходной экономике. Вопросы экономики, 9, 4-17.

Ляско, А. (2003а). Межфирменное доверие и шумпетерианские инновации. Вопросы экономики, 11, 27-40.

Дяско, А. (2003б). Доверие и трансакционные издержки. Вопросы экономики, 1, 42-58.

Мильнер, Б. 3. (1997). Фактор доверия при проведении экономических реформ. Вопросы экономики, 11. 27-38.

Нестеренко, А. Н. (2002). Новые требования и методы взаимодействия организациий с институцциональной средой.
Управление социально-экономическим развитием России. Москва, Россиа: Экономика.

North, D. C. (2003). Institucije, institucionalna promjena $i$ ekonomska uspješnost. Zagreb, Croatia: Masmedia.

Ostrom, E. (1998). A Behavioral Approach to the Rational Choice Theory of Collective Action. American Political Science Review, 92(1), 1-22.

Полтерович, В. М. (2001). Трансплантация экономических институтов. Экономическая наука современной России, 3, 24-50.

Putnam, R. D. (1993). Making Democracy Work. Princeton: Princeton University Press.

Putnam, R. D. (Ed.). (2002). Democracy in Flux: Social Capital in Contemporary Societies. New York, NY: Oxford University Press.

Стиглиц, Дж. (2001). Quis costodiet ipsos custodies? Неудачи корпоративного управления при переходе к рынку. Экономическая наука современной России, 4, 108-146.

Uslaner, E. (2002). The Moral Foundation of Trust. New York, NY: Cambridge University Press.

Uslaner, E., \& Badescu, G. (2002, November 22-23). Honesty, Trust and Legal Norms in the Transition to Democracy. Paper presented at the Conference, Workshop on Formal and Informal Cooperation, Budapest.

Zak, P.J., \& Knack, S. (2001). Trust and grouth. The Economic Journal, 111(470), 295-321.

Primljeno 14. juna 2012, nakon revizije, prihvaćeno za publikovanje 9. jula 2012.

Vlastimir Leković je vanredni profesor na Ekonomskom fakultetu Univerziteta u Kragujevcu. Izvodi nastavu iz nastavnih disciplina Komparativni ekonomski sistemi i Ekonomija javnog sektora. Doktorirao je na Ekonomskom fakultetu Univerziteta u Kragujevcu, iz oblasti ekonomskog sistema. Ključne oblasti njegovog istraživačkog interesovanja su ekonomski sistem, ekonomska politika i institucionalna ekonomija. 